\title{
Irrigation Requirements and Yields of Maize Crop Under Future Climate in Some Cities of Northern Cameroon
}

\author{
Charveline Francine Donfack ${ }^{1}$, Brice B. S. Wandjie ${ }^{2}$, Andre Lenouo ${ }^{2}$, David Monkam ${ }^{2} \&$ Clement Tchawoua $^{1}$ \\ ${ }^{1}$ Department of Physics, Faculty of Science, University of Yaoundé I, Cameroon \\ ${ }^{2}$ Department of Physics, Faculty of Science, University of Douala, Cameroon \\ Correspondence: Charveline Francine Donfack, Department of Physics, Faculty of Science, University of \\ Yaoundé I, Cameroon, P.O. Box 812 Yaounde, Cameroon. Tel: 237-691-271-190. E-mail: \\ frcharveline@gmail.com
}

Andre Lenouo, Department of Physics, Faculty of Science, University of Douala, Cameroon, P.O. Box 24157 Douala Cameroon. Tel: 237-675-725-294. E-mail: lenouo@yahoo.fr

Received: May 28, 2020

doi:10.5539/jas.v12n8p226
Accepted: June 30, $2020 \quad$ Online Published: July 15, 2020

URL: https://doi.org/10.5539/jas.v12n8p226

\begin{abstract}
Using meteorological data obtained from Regional Model (REMO), maize yields from the years 2020 to 2099 were simulated by AquaCrop Model in Maroua, Garoua and Kaélé. These future yields are almost nil for the three cities. In view to determine the minimum quantities of water needed to improve them, the hypothesis of no water moisture stress was considered. For the four periods of 20 consecutive years (2020-2039, 2040-2059, 2060-2079 and 2080-2099), average yields of 5.21, 5.11, 4.97, and 4.73 ton/ha are obtained in Garoua, 5.05, 4.97, 4.64, and 3.87 ton/ha in Maroua and 4.91, 4.82, 4.51 and 3.69 t/ha in Kaélé. The average quantities of water irrigation (also obtained with AquaCrop) for the same periods are 13, 19, 46 and $78 \mathrm{~mm}$ for Garoua; 34, 48, 84 and $147 \mathrm{~mm}$ for Maroua and 57, 68, 111 and $171 \mathrm{~mm}$ for Kaélé. The yields by considering these irrigation water quantities are improved and the following values are obtained for the four periods indicated above: 5.20, 5.10, 4.99 and 4.82 ton/ha for Garoua; 5.10, 5.00, 4.78 and 4.35 ton/ha for Maroua and 4.99, 4.91, 4.75 and 4.50 ton/ha for Kaélé.
\end{abstract}

Keywords: future climates, maize crop yields, irrigation, AquaCrop, Northern Cameroon

\section{Introduction}

Climate change is of concern for all the countries in the world and its consequences are related to a significant threat to the Goals achievement of sustainable development and growth in Africa (FPA, 2017; Inoussa, 2010). Future climate trends predict that large areas including the Sahel, the Horn of Africa, parts of central and southern Africa, could be warmed by about 3 to $6{ }^{\circ} \mathrm{C}$ by 2100 for an average of $4.5^{\circ} \mathrm{C}$ (IPCC, 2007). It's also expected that rainfall patterns will be affected and may fall by more than 20 to 30 percent from the WMO baseline of 1961-1990 (Bigot et al., 1997). Sanderson et al. (2011) projected for these regions a faster temperature rise than the global average increase during the twenty-first century. Unfortunately these predictions could be realized because according to the IPCC Fifth Assessment Report (Niang et al., 2014), an increase in the surface temperature was observed in Sahel region over the last 50 years. Also, New et al. (2006) noticed that the number of cold days and nights are decreasing. All these climatic changes will have important effects on activities such as livestock farming, hydropower generation and agriculture which are highly dependent on the climate and African countries for which, the economy is based on these activities will be greatly affected. Studies carried out in Senegal (Seck et al., 2005) and Niger (Salack et al., 2006) for example have shown that agricultural yields are experiencing drastic deficits due to the adverse effects of these climatic changes and their estimation by 2050 indicate very significant declines. Studies conducted by the IPCC (2017) indicate that by 2020, rainfed agricultural yields could fall by $50 \%$ due to soil moisture stress and 75 to 250 million people in Africa will be affected.

With the Democratic Republic of Congo, Cameroon plays a significant role in agricultural production in Central Africa and both countries contribute for about 36\% to sub-regional agricultural Gross Domestic Product (Agritrade, 2011). It has the most resilient economy owing to diversification and its resources consist of oil, 
mining, agro-food and agricultural products such as cotton, coffee, wood etc. About $73 \%$ of its active population depends on the agricultural sector for employment (Molua \& Lambi, 2006). Maize is highly produced there because of its high solar radiation, low night temperatures, low incidence of pests and diseases (Oyekunle, 2014). This cereal is mainly cultivated in the northern part of the country and climate is an important parameter for good production (Epule, 2015). This Northern part of the country consists of three regions with fairly close climates. The region of Adamaoua located at latitude $7^{\circ} 05^{\prime} 06.00^{\prime \prime}$ North and longitude $13^{\circ} 12^{\prime} 10.80^{\prime \prime}$ has three types of climate: in the south, it is an equatorial climate of Guinean type, on the highland, it is the tropical Sudanian type and in the southwest of Adamaoua, it is an equatorial climate of Cameroonian type. The northern region extends between $8^{\circ}$ to $10^{\circ}$ North latitude and between $12^{\circ}$ to $16^{\circ}$ East longitude and its climate is Sudanian. The third region is the Far north; it is located at latitude $11^{\circ} 3^{\prime} 43.20^{\prime \prime}$ North and longitude $14^{\circ} 33^{\prime} 03.60^{\prime \prime}$ East; its climate is desert. The increase of the mean temperature noticed in this Northern region of Cameroon has led to shortening of the time of crop maturity, less grain production and water stress (Chabejong, 2016). Chuku and Okoye (2009) outline four main adaptation strategies that can be applied in this region to cope with climate change: granting credit to farmers; implementing policies and programs that will influence the use of land and water resources; production methods, land use, land topography, irrigation and timing and finally, the developing of new crop varieties which best suit the climate information systems. Crop irrigation and rainwater harvesting are efficient strategies and have seen sustainability in other parts of Africa (AFRHINET). It could be feasible if implemented in the Northern region of Cameroon. We have previously shown for example that maize can be grown twice a year in these three regions if steps are taken to properly irrigate the plants (Donfack et al., 2018). It is therefore interesting to determine the impact of future climates on the production yields of this crop in this Northern part of Cameroon and plan the ways to remedy to the situation.

Several models such as WOFOST (Supit, 1994), Cropsyst (Stöckle et al., 2003), APSIM (McGown et al., 1996), DSSAT (Jones et al., 2003), EPIC (Williams et al., 1989), STICS (Brisson et al., 1998), AquaCrop (Steduto et al., 2009) have been designed and allow making such studies. AquaCrop model differs from others by its balance between precision, simplicity, robustness and its suitability to dealing with conditions where water is a limiting factor in agricultural production. Moreover, it simulates rainfed agriculture, additional deficit and total irrigation (Steduto et al., 2007), hydrological flow parameters. It takes into consideration the soil water content in the profile and compartments as well as the net irrigation needs (Raes et al., 2009), crop sequences and analysis of climate scenarios (FAO, 2020). It has been successfully used to predict yields of some culture like maize and sorghum in future water availability scenarios in Kenya (Abedinpour et al., 2014; Mwangi et al., 2019) and other countries in the world ( Olivier et al., 2016). In this work, it was used to study the maize yields in the cities of Garoua, Kaélé and Maroua, three main cities of the Northern region of Cameroon. The impacts of the climate from 2020 to 2099 on the yields of maize crops and the irrigation proposals to remedy to the situation are presented.

\section{Materials and Methods}

\subsection{Study Areas}

This study was carried out in the cities of Garoua, Kaélé and Maroua located in regions of Northern Cameroon. Figure 1 shows the localization of these cities on the Cameroon map and Table 1, their geographical coordinates. 


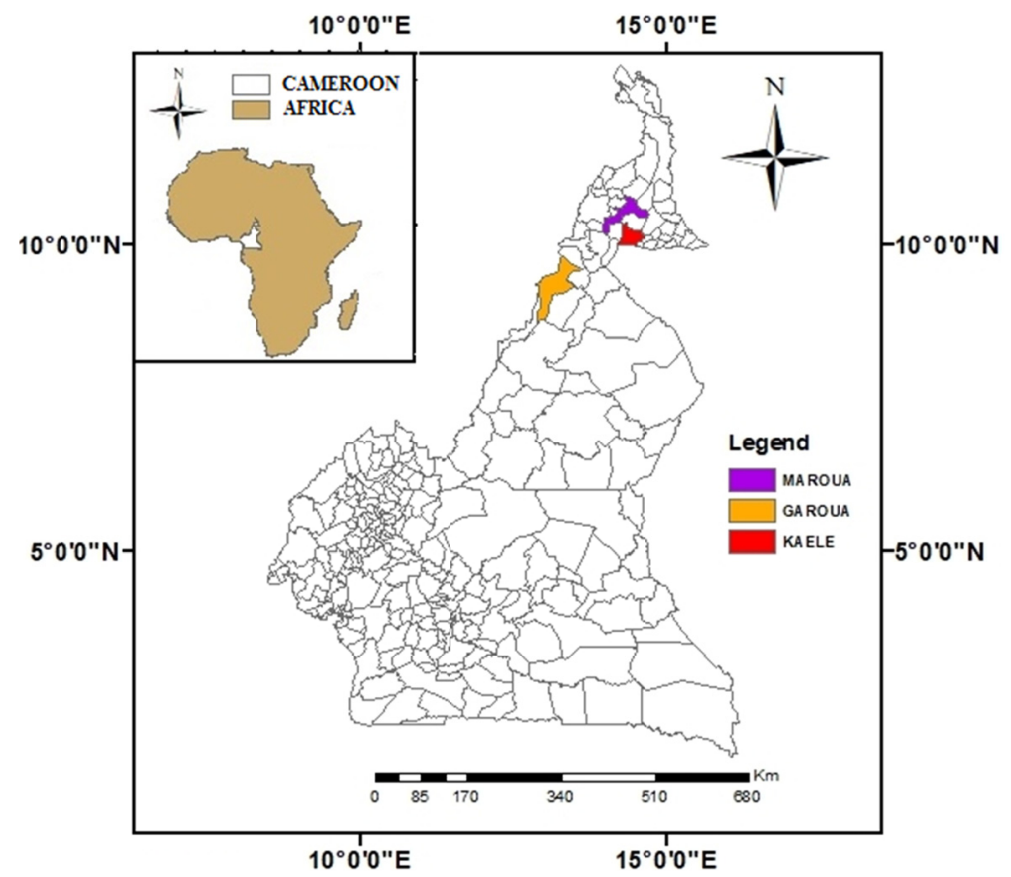

Figure 1. Cameroon map showing the localization of the study areas. Inset map showing the localization of Cameroon in Africa

Table 1. Geographical coordinates and climate of the study areas

\begin{tabular}{lllll}
\hline Study areas & Region & Latitude & Longitude & Climate \\
\hline Garoua & North & $09^{\circ} 18^{\prime}$ & $13^{\circ} 24^{\prime}$ & Sudanese \\
Kaélé & Far North & $10^{\circ} 05^{\prime} 44^{\prime \prime}$ & $14^{\circ} 26^{\prime} 37^{\prime \prime}$ & Sudano-Sahelian \\
Maroua & Far North & $10^{\circ} 35^{\prime}$ & $14^{\circ} 19^{\prime}$ & almost semi-desert \\
\hline
\end{tabular}

\subsection{Data for the Study}

The past climatic data used in this work are observation data from the MAAM project (Multidisciplinary Analysis of the African Monsoon) recorded at the weather stations of Garoua and Maroua during the period from 1999 to 2004. The climatic data for the period of 2020-2099 used to generate future maize yields in the three cities were extracted from the Central African data simulated under REMO model coupled with the overall MPI-ESM of the RCP8.5 scenario (Fotso et al., 2016). Phenological data of maize grown in the three cities were obtained from the Agricultural Research Institute for Development (IRAD) of Cameroon and they are summarized in Table 2. The observed yields in the field were obtained from the Ministry of Agriculture and Rural Development of Cameroon. The physical and chemical properties of the soil were obtained from the Development Research Institute (IRD) of Cameroon.

Table 2. Phenological data of the maize variety studied

\begin{tabular}{llllll}
\hline Variety & Nature & $\begin{array}{l}\text { Potential } \\
\text { Yield }\end{array}$ & $\begin{array}{l}\text { Seed-to-maturity } \\
\text { cycle }\end{array}$ & $\begin{array}{l}\text { Adaptation area/ } \\
\text { regions in Cameroon }\end{array}$ & Particularity \\
\hline $\begin{array}{l}\text { AYUK TAKEM } \\
\text { (CMS9015) }\end{array}$ & composite & $3-4$ ton/ha & 90-95 days & $\begin{array}{l}\text { Center, south, east, } \\
\text { coastline, north, } \\
\text { far north, south west }\end{array}$ & $\begin{array}{l}\text { Intermediate and therefore } \\
\text { adapted to areas with low rainfall }\end{array}$ \\
\hline
\end{tabular}

\subsection{Presentation of REMO Model, Future Temperatures and Rainfalls for the Three Cities}

The regional climatic model REMO is suitable for climate modeling and meteorological forecasts. It was developed as an atmospheric component of the coupled atmosphere-hydrology model system. The dynamic core of REMO is based on an improved version of that of Europa-Model (EM). The characteristics of REMO model are summarized in Table 3. It was successfully used to simulate future rainfall and temperature over central 
Africa for the period of 2006-2100 (Fotso et al., 2016). Figure 2 presents the variations of these two climatic parameters from 2020 to 2100 for the cities of Garoua, Kaélé and Maroua, the studied areas of this work.

Table 3. Characteristics of REMO model

\begin{tabular}{|c|c|c|c|c|c|c|c|c|}
\hline $\begin{array}{l}\text { Model } \\
\text { version }\end{array}$ & $\begin{array}{l}\text { Vertical } \\
\text { coordinate/ } \\
\text { Levels }\end{array}$ & $\begin{array}{l}\text { Advection scheme/ } \\
\text { Time step }\end{array}$ & $\begin{array}{l}\text { Convective } \\
\text { scheme }\end{array}$ & Radiation scheme & $\begin{array}{l}\text { Turbulence } \\
\text { vertical } \\
\text { diffusion }\end{array}$ & $\begin{array}{l}\text { Cloud } \\
\text { microphysics } \\
\text { scheme }\end{array}$ & $\begin{array}{l}\text { Land } \\
\text { surface } \\
\text { scheme }\end{array}$ & $\begin{array}{l}\text { Scheme of the } \\
\text { boundary layer }\end{array}$ \\
\hline $\begin{array}{l}\text { REMO } 2009 \\
\text { hydrostatic }\end{array}$ & Hybrid/27-31 & Semi-lagragien/240s & $\begin{array}{l}\text { Tiedtke (1989); } \\
\text { Nordeng (1994); } \\
\text { Pfeifer (2006) }\end{array}$ & $\begin{array}{l}\text { Morcrette et al. (1986) } \\
\text { Giogetta \& Wild (1995) }\end{array}$ & Louis (1979) & $\begin{array}{l}\text { Lohman \& } \\
\text { Roeckner (1996) }\end{array}$ & $\begin{array}{l}\text { Hagemann } \\
\text { et al. (2002) }\end{array}$ & Davies (1976) \\
\hline
\end{tabular}

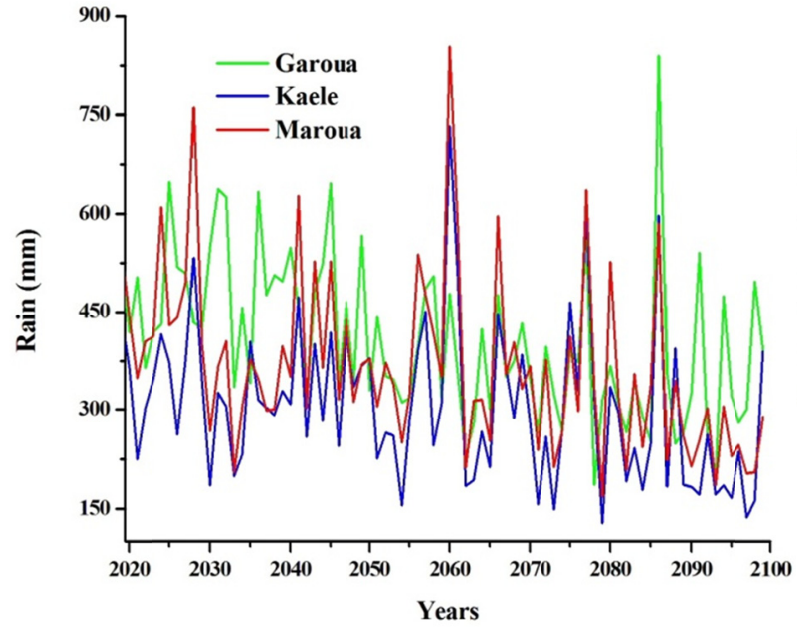

(a)

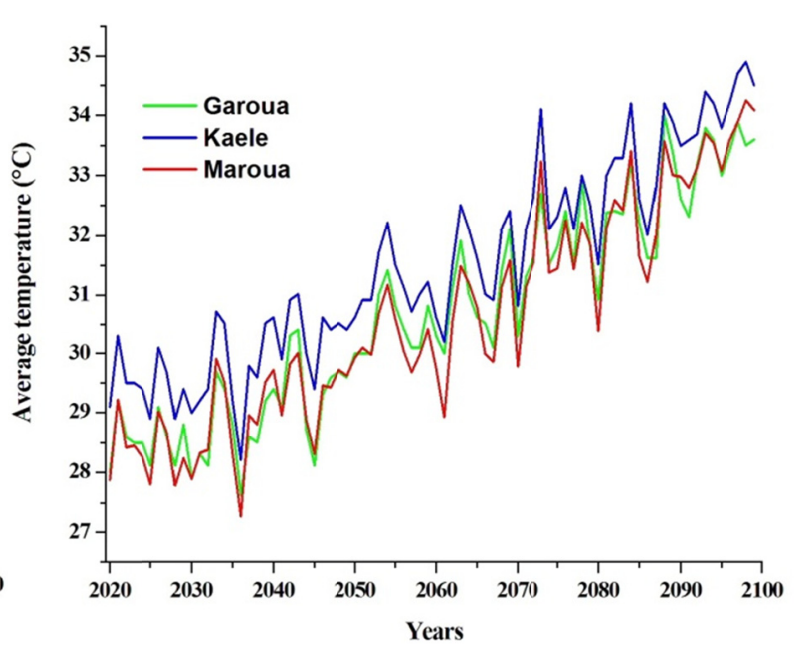

(b)

Figure 2. Trends of: (a) rainfall and (b) average temperature from 2010 to 2100 in Maroua, Garoua and Kaélé

\subsection{Presentation of AquaCrop Model and Calibration}

\subsubsection{Presentation of the AquaCrop Model}

AquaCrop is a model developed by FAO that simulates the response of crop growth and crop yield under future climate scenarios. The model is particularly useful for developing irrigation strategies under water deficit conditions, to study the effect on the yield of the site, the type of soil, the date of sowing. It also studies the effect of different land management techniques on yield. It compares actual and optimal yields on a plot, perimeter or region, identifies constraints limiting crop production and water productivity, predicts the impacts of climate changes on agricultural production. Its principle is based on the simulation of the water yield response with the following steps:

- Simulation of the development of the green Canopy Cover (CC),

- Simulation of the transpiration of the crop,

- Simulation of biomass,

- Simulation of the final crop yield.

Figure 3 gives the calculation scheme of AquaCrop model (Raes et al., 2009).

The response of the yield to the developed water is given by Doorenbos \& Kassam (1979) in the FAO document from the Ky approach by Equation 1.

$$
\left(1-\frac{Y}{Y_{X}}\right)=K_{y}\left(1-\frac{E T}{E T_{X}}\right)
$$

Where, $\mathrm{Yx}$ and $\mathrm{Y}$ are the maximum and real yield, $(1-\mathrm{Y} / \mathrm{Yx})$ is the relative decline in yield, ETx and ET are the maximum and actual evapotranspiration respectively, $(1-\mathrm{ET} / \mathrm{ETx})$ is the relative water stress and Ky a proportionality factor between the relative decline in yield and the relative reduction in evapotranspiration. 
The AquaCrop model (Steduto et al. 2007, Raes et al., 2009, \& Hsiao et al., 2009) separates, on the one hand, the actual evapotranspiration (ET) in soil evaporation (E) and crop transpiration (Tr) while following the Equation 2.

$$
\mathrm{ET}=\mathrm{E}+\mathrm{Tr}
$$

This separation distinguishes the productive water consumption (transpiration) from the non-productive (evaporation of the soil). This is especially important when the soil cover is incomplete at the beginning of the season or following sparse planting. It separates the final yield (Y), the biomass (B) and the harvest index (HI) by Equation 3.

$$
\mathrm{Y}=\mathrm{HI} \cdot(\mathrm{B})
$$

These separations lead to the conceptual equation (see Equation 4) at the heart of the AquaCrop growth engine.

$$
\mathrm{B}=\mathrm{WP} \cdot \mathrm{Tr}
$$

Where, Tr is the transpiration of the crop (in $\mathrm{mm}$ ) and WP is the water productivity (biomass per unit of cumulative transpiration), which tends to be constant for a given climatic condition (De Wit 1958; Hanks 1983; Tanner 1983).

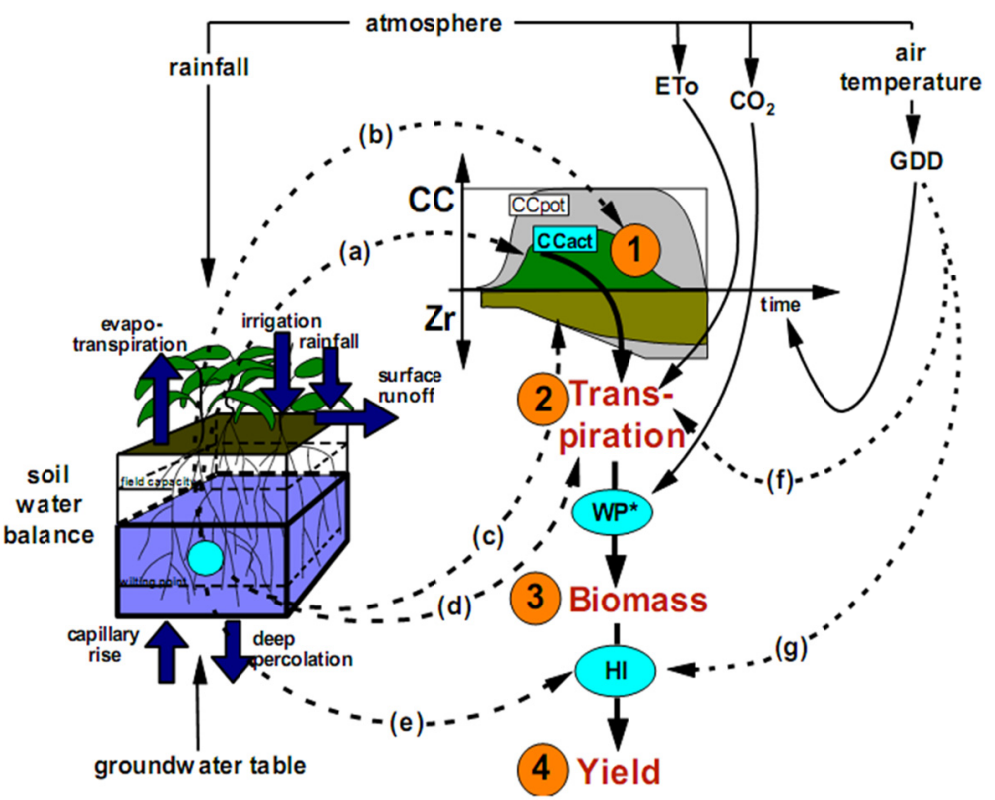

Figure 3. Calculation scheme of AquaCrop with indication of the 4 steps, and the processes (dotted arrows) affected by water stress (a to e) and temperature stress ( $\mathrm{f}$ to $\mathrm{g}$ ). $\mathrm{CC}$ is green canopy cover; $\mathrm{Zr}$, rooting depth; ETo, reference evapotranspiration; WP*, normalized biomass water productivity; HI, harvest index; and GDD, growing degree day. Water stress: (a) slows canopy expansion, (b) accelerates canopy senescence, (c) decreases root deepening but only if severe, (d) reduces stomatal opening and transpiration, and (e) affects harvest index. Cold temperature stress (f) reduces crop transpiration. Hot or cold temperature stress (g) inhibits pollination and reduces HI (Raes et al., 2009)

\subsubsection{Data Used for Calibration in This Work}

The calibration of AquaCrop requires climate data, soil parameters and crop management.

\section{(1) Climatic Parameters}

At the input of the model (the daily values of minimum and maximum air temperature, the daily average precipitation and the real evapotranspiration (ETo) were introduced. ETo was estimated with an ETo calculator using the maximum and minimum daily temperature, the wind speed at $2 \mathrm{~m}$ above the ground surface, the solar radiation and the average relative humidity for the period of 1999-2004 corresponding to the evaluation period used in this work. 


\section{(2) Parcel Management}

All the soil management variables were calibrated according to the soil texture of the sites studied. The parameters (saturation hydraulic conductivity, saturation soil water content, field capacity, permanent wilting point, permeability, rate of expansion of the root zone, useful soil water reserve, soil thickness and plant roots) corresponding to the texture of the soils of the studied areas (sandy clay loam) already calibrated in the model (see Table 4 \& Figure 4), were used.

Table 4. Physical characteristics of the soil

\begin{tabular}{lllll}
\hline Saturation (vol \%) & Field capacity (vol \%) & Permanent wilting point (vol \%) & Saturation hydraulic conductivity (mm/day) & Permeability (\%) \\
\hline 47.0 & 32.0 & 20.0 & 225.0 & 100 \\
\hline
\end{tabular}

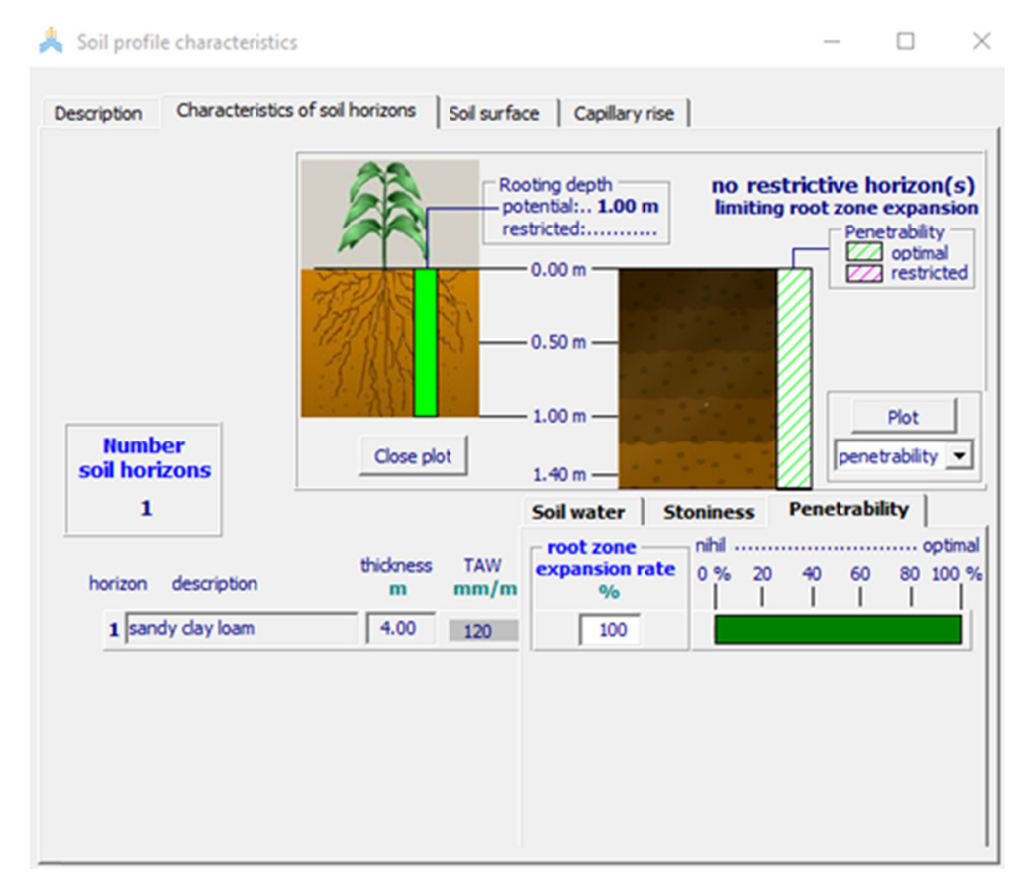

Figure 4. Captured window of Aquacrop model for soil data parameterization

\section{(3) Culture Management}

The corn used for our study is the AYUK TAKEM corn variety (CMS9015). The default input parameters of the model for plant corn presented by Raes et al. (2009) were used. But the maximum plant cover, the plant density, the rooting depth and the duration of the growth cycle, were modified accordingly to the data obtained from the studied areas.

\section{(4) Field Yields}

The field yields used in this work were obtained after processing of the estimates made in the field by the agricultural district delegates and the heads of agricultural posts. These yield data related to each areas of the country are recorded in the annual report of agricultural statistics "AGRI-STAT" provided by the Ministry of Agriculture and Rural Development. A method is developed at the direction of surveys and agricultural statistics so that the data produced is realistic enough. For our study cities, these yields vary from 0 to 3 ton $/ \mathrm{ha}$.

\subsubsection{Calibration, Evaluation and Validation of the AquaCrop Model}

Once the climatic data, the soil data and the yields in the field were collected, we carried out the calibration of AquaCrop model by adjusting the harvest index HI until the yields obtained by simulations were close to those in the field. To assess the performance of the model, we compared the observed maize yield data to those simulated by AquaCrop for the period of 1999-2004 in the cities of Garoua and Maroua. For Kaélé, the calibration for Maroua was used because its daily climatic data (temperature and precipitation) were not available and the climates as well as the corn yields for both cities are very close. The following statistical 
indicators, the coefficient of determination $\left(\mathrm{R}^{2}\right)$ of linear adjustment, the absolute mean square error (RMSE), the square root of the normalized mean square error (nRMSE) and the Willmott's agreement index (d) were used. Their expressions are:

$$
\begin{gathered}
R^{2}=\left[\frac{\sum_{i=1}^{n}\left(O_{i}-\bar{O}\right)\left(P_{i}-\bar{P}\right)}{\sqrt{\sum_{i=1}^{n}\left(O_{i}-\bar{O}\right)^{2} \sum_{i=1}^{n}\left(P_{i}-\bar{P}\right)^{2}}}\right]^{2} \\
R S M E=\sqrt{\frac{\sum_{i=1}^{n}\left(P_{i}-O_{i}\right)^{2}}{n}} \\
n R S M E=\frac{1}{\bar{O}} \sqrt{\frac{\sum_{i=1}^{n}\left(P_{i}-O_{i}\right)^{2}}{n}} 100 \\
d=1-\frac{\sum_{i=1}^{n}\left(P_{i}-O_{i}\right)^{2}}{\sum_{i=1}^{n}\left(\left|P_{i}-\bar{O}\right|+\left|O_{i}-\bar{O}\right|\right)^{2}}
\end{gathered}
$$

where, $\mathrm{n}$ is the total number of observations, $\bar{O}$ the observed mean values, $\bar{P}$ the predicted mean values, Oi and $\mathrm{Pi}$ are the observed and predicted values.

The value of the normalized mean square error (NRMSE) lower than $10 \%$ is ideal for modeling. The nRMSE values in the range of $10-20 \%$ and $20 \%$ to $30 \%$, indicate an appropriate and moderate condition in the model predictions respectively. A value more than $30 \%$ indicates the uncertainty of the model (Jamieson et al., 1991). d goes from 0 to 1 with 0 indicating no agreement and 1 indicating a perfect agreement between the predicted and the observed data.

\subsection{Simulations of the Future Yields and Irrigation Management}

The simulations of future maize yields were done on one hand with all the parameters obtained from the calibration and in other hand, in the perfect condition of no water stress before flowering. For the latter, we have chosen to also determine with AquaCrop the quantities of water required for irrigation. These quantities are determined such that the exhaustion of the root zone is just above the threshold of 50\% of RAW (readily available soil water).

\section{Results and Discussions}

\subsection{Calibration and Validation Results of AquaCrop Model}

The parameters set out in Table 5 were taken into consideration for the calibration of the AquaCrop model. The values of $\mathrm{R}^{2}=0.93$ for the city of Garoua and $\mathrm{R}^{2}=0.85$ for the city of Maroua were obtained by comparing the simulated yields with the observed ones (see Figure 5. These values of $\mathrm{R}^{2}$ as well as those of RMSE, nRMSE and $d$ all close to the ideal values for a perfect calibration of the yields (shown in Table 6), show that the relationship between the observed and simulated yield is good. The model is then capable of simulating the yields of maize crops in the studied cities. 
Table 5. Reference parameters used in this work

\begin{tabular}{llll}
\hline & Value & Unit & Comment \\
\hline Base temperature & 10 & ${ }^{\circ} \mathrm{C}$ & $/$ \\
High threshold temperature & 30 & ${ }^{\circ} \mathrm{C}$ & $/$ \\
Duration of cycle & 125 & Days & 95 days \\
Average size of canopy of young plant with $90 \%$ emergence Cco & 0.25 & $\%$ & $/$ \\
Planting method & $/$ & $/$ & Direct \\
Initial Coverage & $/$ & $/$ & Cover of the canopy \\
Maximum Canopy Coverage & 85 & $\%$ & Well covered \\
Number of plants per hectare & 50000 & Plant/ha & $/$ \\
The time from sowing to emergence & 7 & days & $/$ \\
Sowing time at maximum canopy cover & 45 & days & $/$ \\
Sowing time at maximum rooting depth & 45 & days & $/$ \\
Sowing time at beginning of senescence & 75 & days & $/$ \\
Sowing time to maturity & 95 & days & $/$ \\
Sowing time at flowering & 65 & days & $/$ \\
Maximum allowed increase & 36 & days & $/$ \\
Length of flowering stage & 10 & days & $/$ \\
Minimum effective rooting depth & 0.5 & m & $/$ \\
Water stress before flowering & 10 & $\%$ & / \\
Harvest reference index (\%) HI & 25 & $\%$ & \\
\hline
\end{tabular}

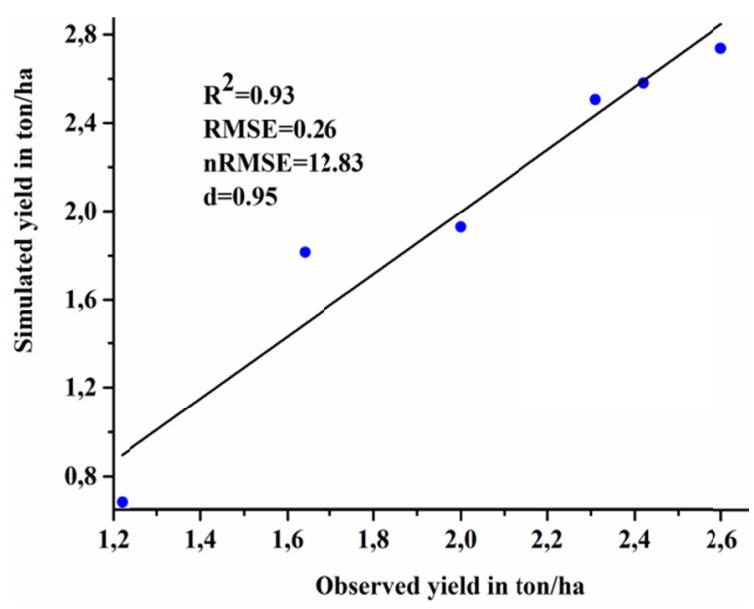

(a)

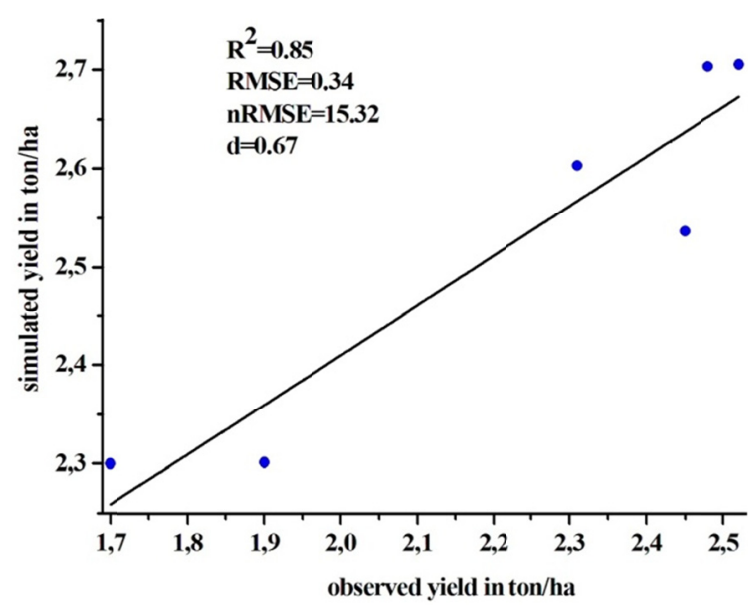

(b)

Figure 5. Relationship between observed and simulated grain yield per hectare for: (a) the city of Garoua and (b) the city of Maroua

Table 6. Statistical parameters for the model performance during calibration

\begin{tabular}{lllll}
\hline & $\mathrm{R}^{2}$ & RMSE & nRMSE in $\%$ & $\mathrm{~d}$ \\
\hline Garoua & 0.93 & 0.26 & 12.83 & 0.95 \\
Maroua & 0.85 & 0.34 & 15.32 & 0.67 \\
Ideal & 1 & 0 & $0<$ nRMSE $<30$ & 1 \\
\hline
\end{tabular}

\subsection{Impact of Future Climate on Maize Crop Yields in the Garoua, Kaélé and Maroua Cities}

All the yields for future climates in the three cities with the parameters obtained during the calibration of the model were nil except very few years between 2020 and 2099. Then, the maize cultures could not be carried out without irrigation in the three cities. Similar results were obtained also for maize by Olivier et al. (2016) in Kazakhstan. In order to find the minimum quantities of water needed; we have simulated the future yields by the 
hypothesis of no water stress of the ground. Figure 6 shows maize crop yields for non-irrigated crops in Garoua (cyan curve), Kaélé (black curve) and Maroua (purple curve) between 2020 and 2099. These curves show that, in general, the yields in the three cities change in the same way. They are higher in Garoua, followed by Maroua and Kaélé. This is related to the weather conditions in these three cities that are more favorable for the development of maize plants in Garoua than Maroua and more than Kaélé as we have observed in our previous work (Donfack et al., 2018). In the city of Garoua, as shown by the cyan curve, the yields are very varied and generally decrease over the years. The high yields correspond to the years for which the rainfall rates are also high. For example from 2020 to 2039 there is an average yield of 5.21 ton/ha for an average rainfall amount of $440.60 \mathrm{~mm}$, from 2040 to 2059 the average yield of 5.11 ton/ha for the average rainfall amount of $390.35 \mathrm{~mm}$. From 2060 to 2079 we note an average yield of 4.97 ton/ha for an average rainfall of $319.85 \mathrm{~mm}$ and from 2080 to 2099 , the average yield of $4.73 \mathrm{ton} / \mathrm{ha}$ for the amount of average rainfall of $293.45 \mathrm{~mm}$. These yields are therefore very affected with the quantities of water in the region and therefore the climate change. This had already been observed in several other semi-arid regions in West Africa (Melki et al., 1995; Doukpolo et al., 2012). However, some yield values do not match expectations based on rainfall rates. This is for example the case of the minimum yield which has a value of $4.15 \mathrm{ton} / \mathrm{ha} \mathrm{(2093)}$ corresponding to the rainfall rate of $172 \mathrm{~mm}$ higher than the minimum rate of $151 \mathrm{~mm}$ (2078). At this rate of rainfall corresponds a yield of $4.40 \mathrm{ton} / \mathrm{ha}$ higher than 4.15 ton/ha (2093). This could be due to the thermal increase because we note a temperature of $33.8{ }^{\circ} \mathrm{C}$ in 2093 while it is $32.9^{\circ} \mathrm{C}$ in 2078. This was also observed by Ferris et al. (1998) in wheat culture in Australia and agrees with the results of Issa (2012) who notes such observations for crops in Benin. In Kaélé, observations are similar as shown by the black curve in Figure 6. On average, yields are in the order of 4.91 ton/ha (2020-2039), $4.82 \mathrm{ton} / \mathrm{ha}(2040-2059), 4.51 \mathrm{ton} / \mathrm{ha} \mathrm{(2060-2079)}$ and $3.70 \mathrm{ton} / \mathrm{ha} \mathrm{(2080-2099)}$ for mean rainfall rates of 280.75 $\mathrm{mm}, 275.55 \mathrm{~mm}, 263.65 \mathrm{mmm}$ and $206.6 \mathrm{~mm}$ respectively. However, it can be seen that for a low rain rate there is not always a low yield, this is for example the case for the years 2089 and 2093 where the rainfall rates are $147 \mathrm{~mm}$ and $161 \mathrm{~mm}$ and the yields; $3.67 \mathrm{ton} / \mathrm{ha}$ and $1.55 \mathrm{ton} / \mathrm{ha}$ respectively. This would also be due to the thermal increase because we note a temperature of $33.9^{\circ} \mathrm{C}$ in 2089 and $34.4^{\circ} \mathrm{C}$ in 2093 . In the city of Maroua, the same observations are also made as shown by the purple curve of Figure 6. On average, yields are in the range of 5.055 ton/ha (2020-2039), 4.970 ton/ha (2040-2059), 4.639 ton/ha (2060-2079) and 4.868ton/ha (2080-2099) for average rainfall amounts of $370.25 \mathrm{~mm}, 357.75 \mathrm{~mm}, 316.2 \mathrm{~mm}$ and $264.15 \mathrm{~mm}$ respectively. Thus, in general, the yields always vary in the same direction as the rainfall but irregularities due to the thermal increase are sometimes noted.

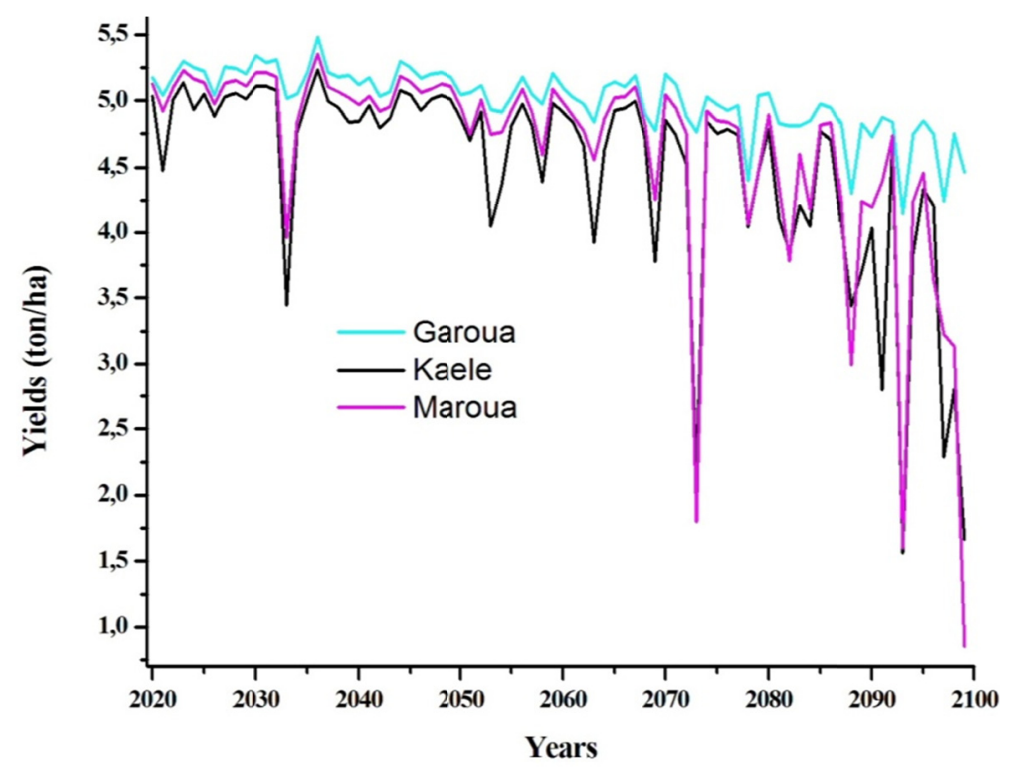

Figure 6. Yields of non-irrigated maize crops in the Garoua (cyan curve), Kaélé (black curve) and Maroua (purple curve) cities of 2020 to 2099 


\subsection{Comparison of Future Yields With Those of Previous Years in the Cities of Garoua, Kaéle and Maroua}

Table 7 gives simulated mean future yields of maize plants for the periods from 2020 to 2039, 2040 to 2059, 2060 to 2079 and 2080 to 2099 compared to the reference period 1979-2004 (Garoua and Maroua) and 1970-1985 (Kaélé).

Table 7. Future average simulated maize crop yields (ton/ha) for the periods 2020-2039, 2040-2059, 2060-2079, 2080-2099 and their variation rates with reference to the periods 1979-2004 (Garoua and Maroua) and 1970-1985 (Kaélé)

\begin{tabular}{|c|c|c|c|c|c|c|c|c|c|}
\hline & \multirow{3}{*}{$\begin{array}{l}\text { Garoua, Maroua (1979-2004); } \\
\text { Kaélé (1970-1985) } \\
\text { Ton/ha }\end{array}$} & \multicolumn{8}{|c|}{ Yields Without Irrigation } \\
\hline & & \multicolumn{2}{|c|}{ 2020-2039 } & \multicolumn{2}{|c|}{ 2040-2059 } & \multicolumn{2}{|c|}{$2060-2079$} & \multicolumn{2}{|c|}{ 2080-2099 } \\
\hline & & Ton/ha & $\%$ & Ton/ha & $\%$ & Ton/ha & $\%$ & Ton/ha & $\%$ \\
\hline Garoua & 5.38 & 5.21 & -3 & 5.11 & -5 & 4.97 & -8 & 4.73 & -12 \\
\hline Kaélé & 5.53 & 4.91 & -11 & 4.82 & -13 & 4.51 & -18 & 3.69 & -33 \\
\hline Maroua & 5.52 & 5.05 & -8 & 4.97 & -10 & 4.64 & -16 & 3.87 & -30 \\
\hline
\end{tabular}

The comparative analysis of the simulated yields of maize crops by 2099 compared to the reference period 1979-2004 (Garoua and Maroua) and 1970-1985 (Kaélé) show progressively large decreases over the years. The mean varies from 3 to $12 \%$ for the city of Garoua, 11 to $33 \%$ for Kaélé and 8 to $30 \%$ for Maroua. These results show that the cultivation of maize plants will be more affected in the cities of Kaélé and Maroua compared to Garoua. Changes in precipitation rates due to climate change could be the main cause as also observed by Olivier et al. (2016) with the cultures of wheat, corn, and sunflower in Russia, Ukraine, and Kazakhstan. To overcome these shortcomings for plant development, irrigation is the best strategy as indicated above.

\subsection{Quantities of Irrigation Water to Boost the Yields}

Figures 7, 8, 9 and 10 shows the future yields of maize plants obtained from 2020 to 2099 using the AquaCrop model without and with irrigation and the quantities of net water needed to irrigate these plants in the city of Garoua.
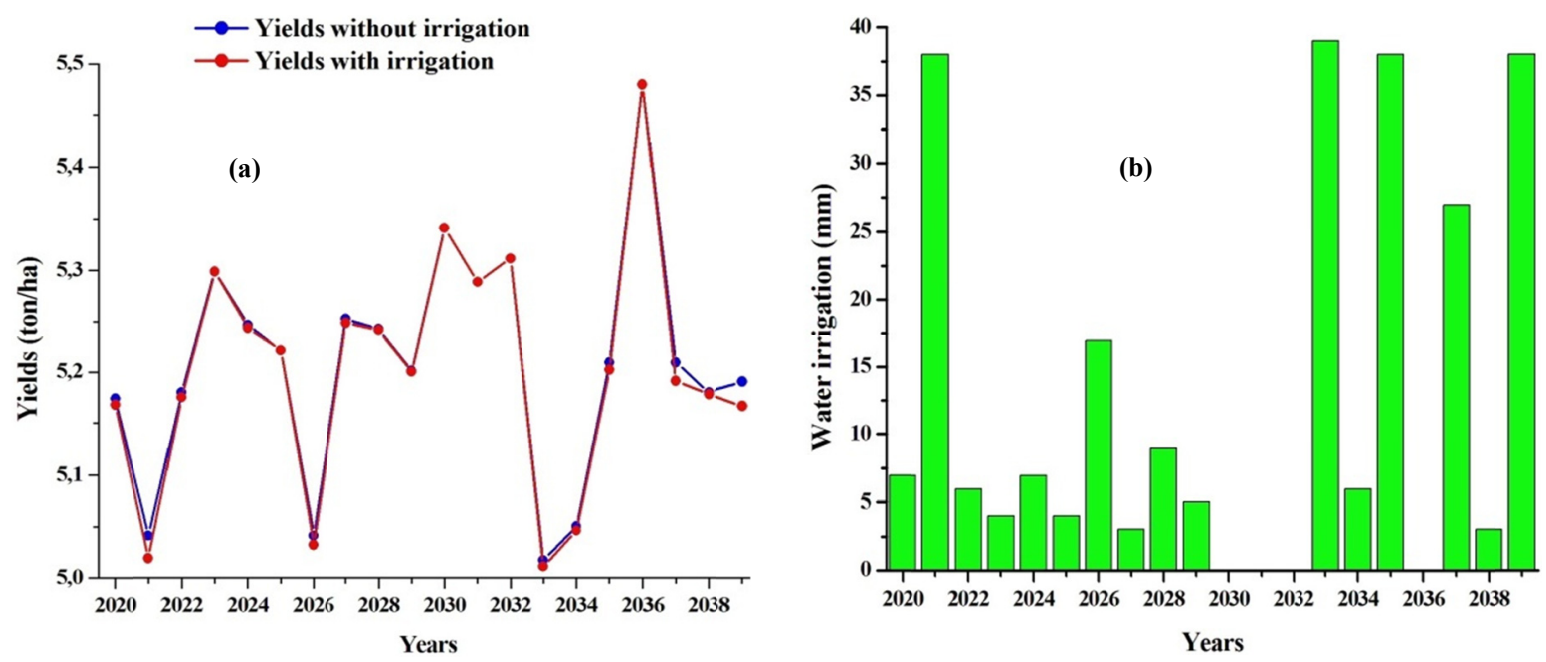

Figure 7. Diagrams showing between 2020 and 2039 in (a) variations in yields of maize with and without irrigation and (b) amounts of water to bring for irrigation in the city of Garoua 

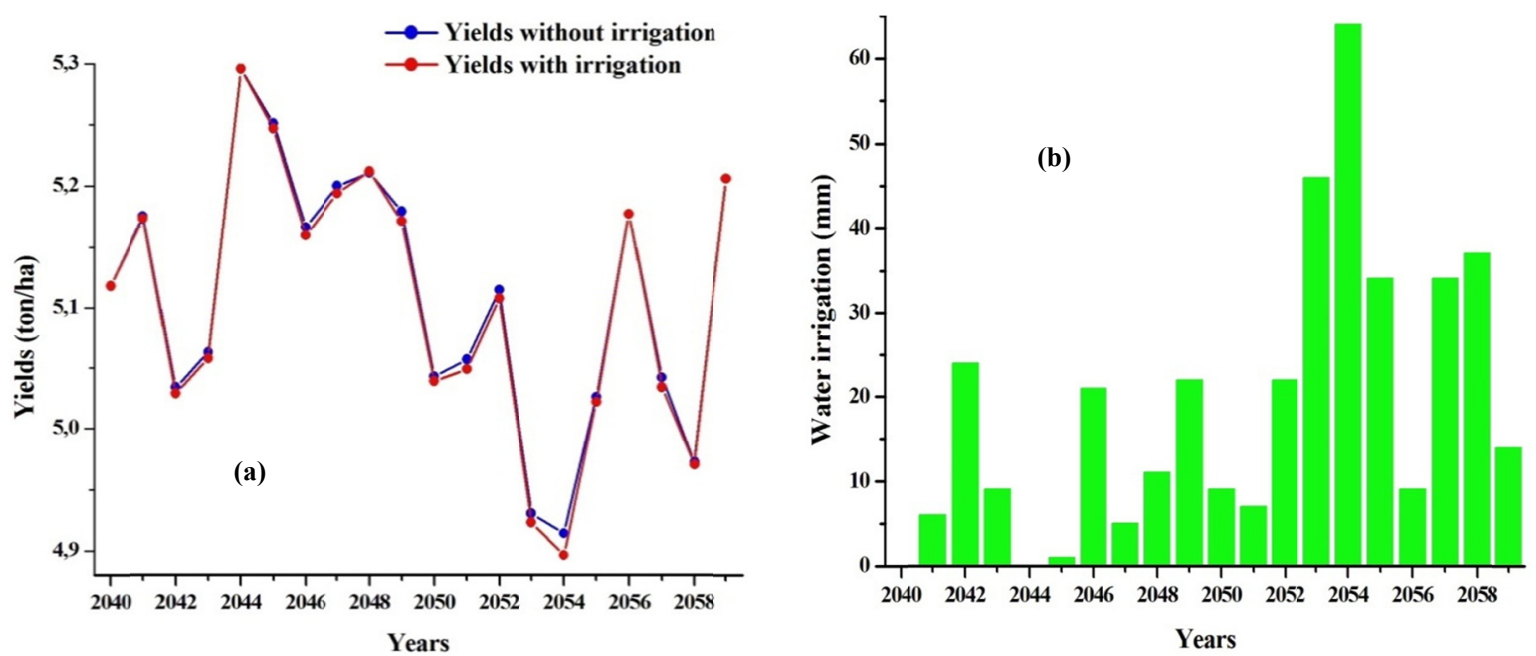

Figure 8. Diagrams showing between 2040 and 2059 in (a) the variations of maize yields with and without irrigation and (b) the quantities of water to be brought for irrigation in the city of Garoua
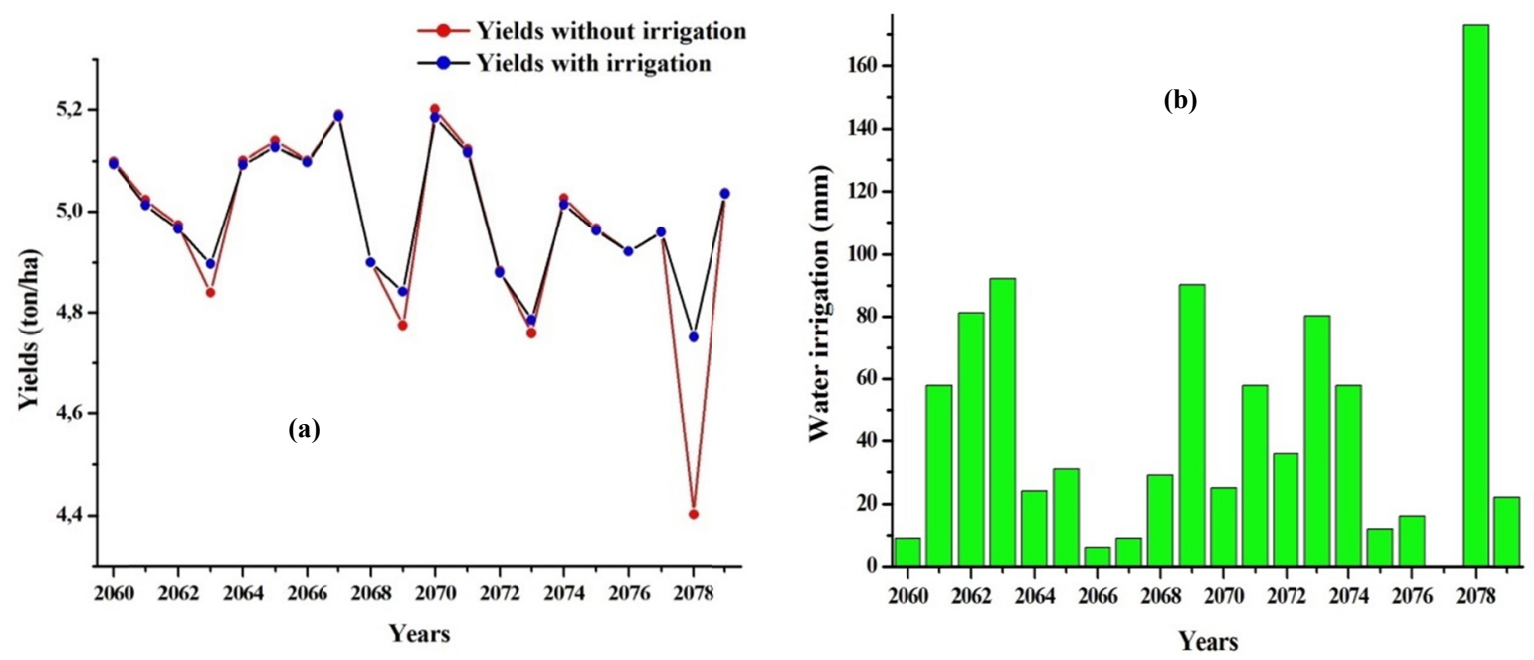

Figure 9. Diagrams showing between 2060 and 2079 in (a) the variations of maize yields with and without irrigation and (b) the quantities of water to be brought for irrigation in the city of Garoua
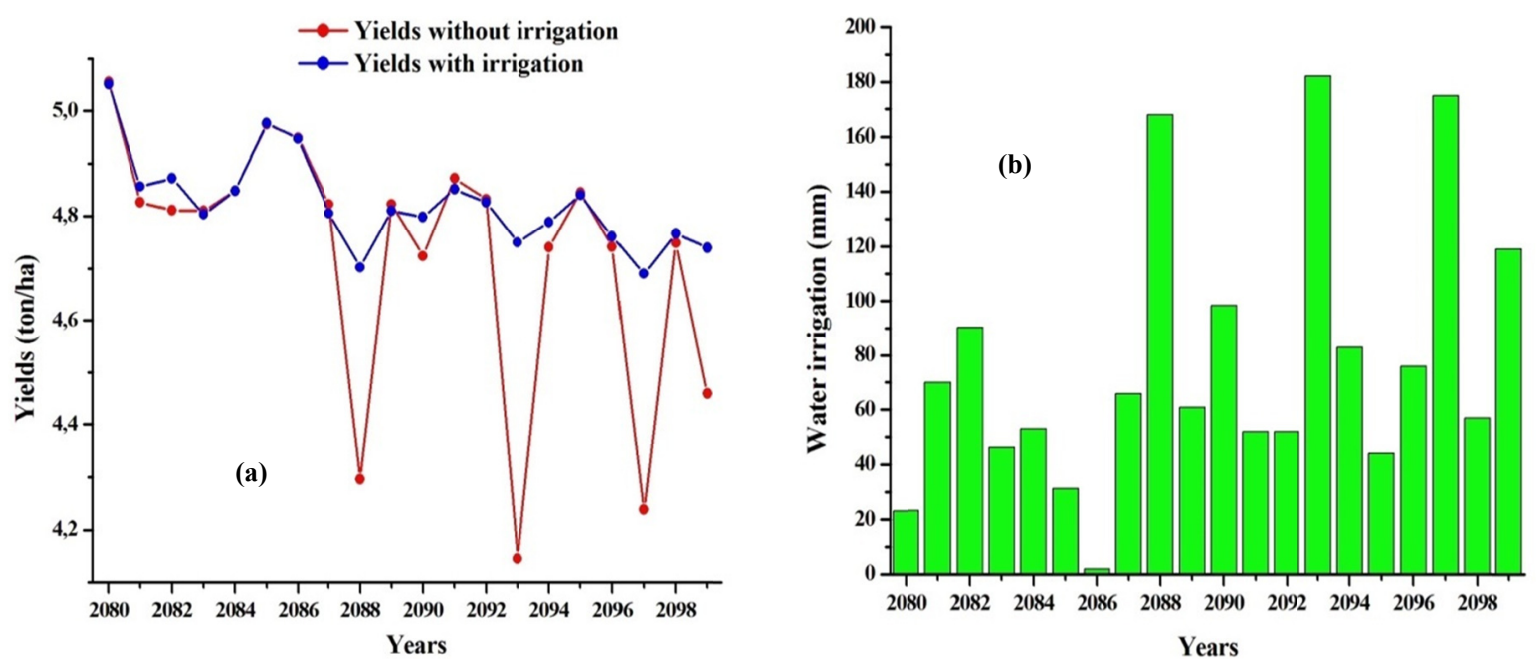

Figure 10. Diagrams showing between 2080 and 2099 in (a) the variations of maize yields with and without irrigation and (b) the quantities of water to be brought for irrigation in the city of Garoua 
These figures show that, the simulated yields with irrigation are almost equal to those simulated without irrigation and the water levels required for this process are less than $100 \mathrm{~mm}$. In 2036, the irrigation rate is nil. This can be explained by the fact that the quantity of water brought by the rains is slightly sufficient for the normal development of maize plants. However, it can be seen that during the years 2078, 2088, 2093, 2097 and 2099 the simulated yields with irrigation are different from those simulated without irrigation. This is due to the fact that the amounts of rain are lower for these years. Indeed we note that for these years the rainfall rates are 151, 189, 172, 178 and $213 \mathrm{~mm}$ which are lower than $361 \mathrm{~mm}$ the average rate, As a result, the quantities of water required for irrigation during these years are greater (greater than $100 \mathrm{~mm}$ ) and the yields are improved. These results thus show that the impact of climate change in the city of Garoua on maize cultivation is very low until 2078 and become more important later. A similar result was observed by Kate et al. (2017); and Chebil (2011) who found that climate impacts will be greatest for maize cultivation by 2050 and for cereal crops (durum wheat, soft wheat and barley) by 2030 .

Figures 11, 12, 13 and 14 show the future yields of maize plants obtained for the same periods also using the AquaCrop model without and with irrigation and the quantities of net water needed for irrigation in the city of Kaélé.
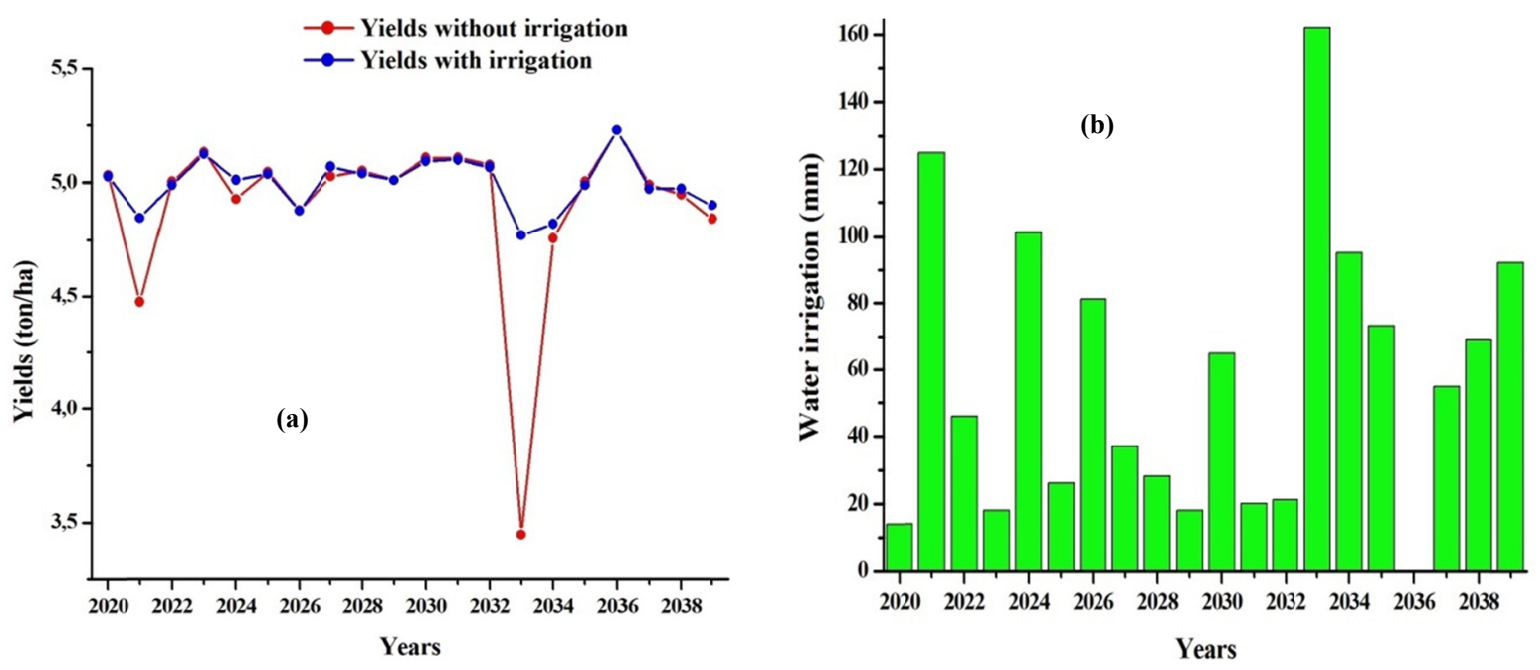

Figure 11. Diagrams showing between 2020 and 2039 in (a) changes in yields of maize with and without irrigation and (b) amounts of water to be supplied for irrigation in the city of Kaélé
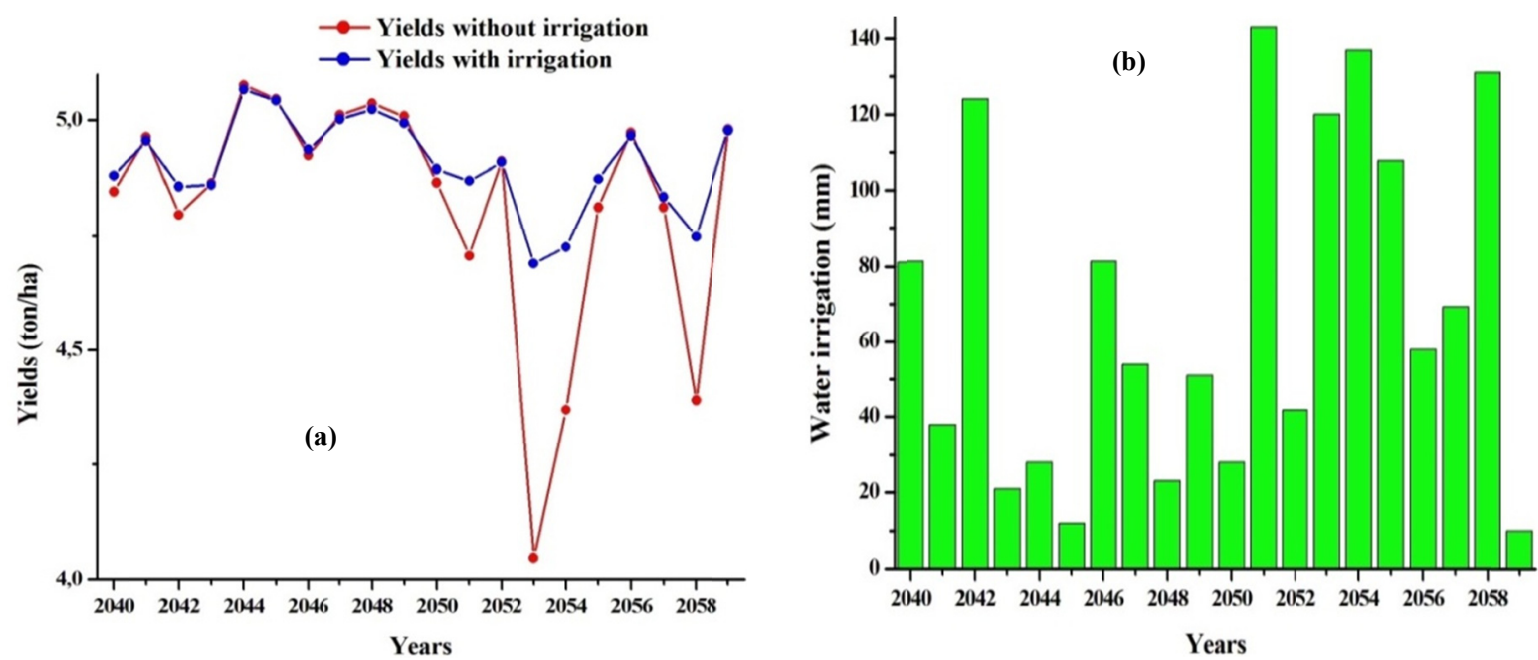

Figure 12. Diagrams showing between 2040 and 2059 in (a) the variations in maize yields with and without irrigation and (b) the quantities of water to be supplied for irrigation in the city of Kaélé 

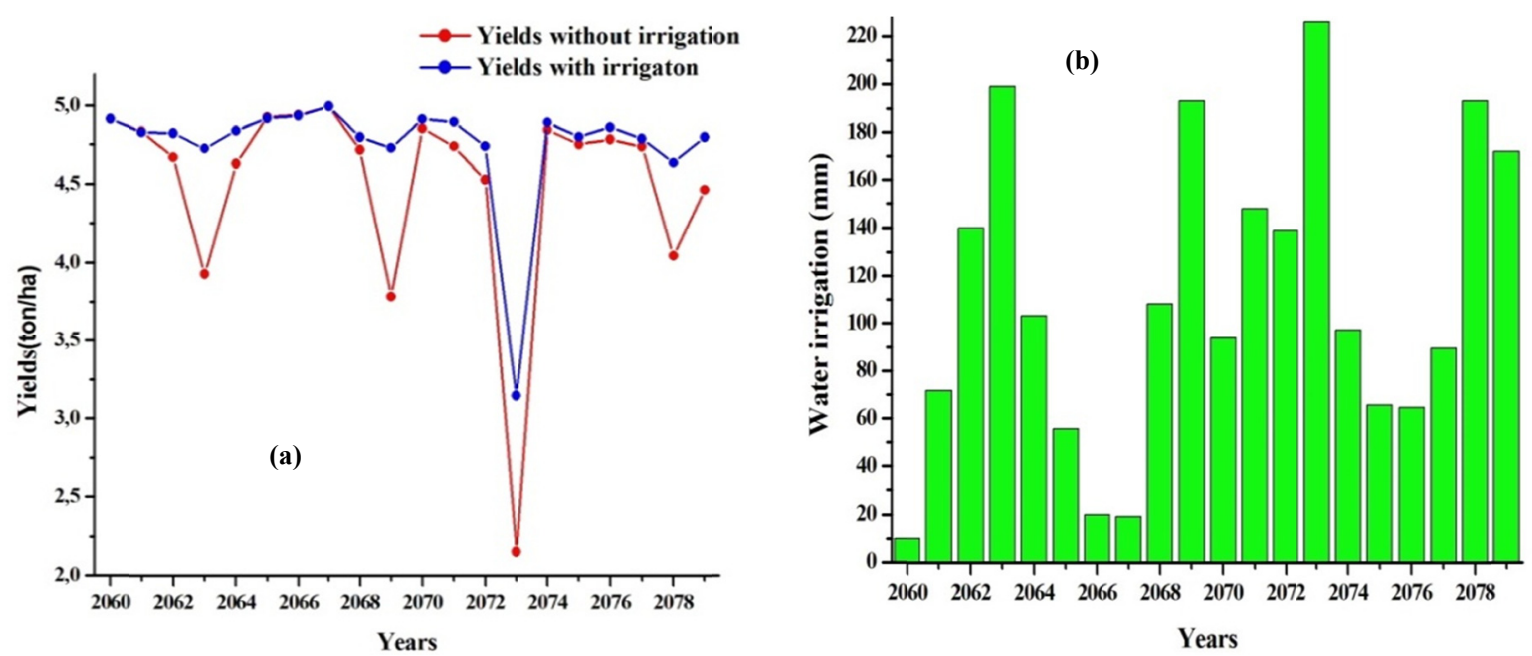

Figure 13. Diagrams showing between 2060 and 2079 in (a) the variations in maize yields with and without irrigation and (b) the quantities of water to be supplied for irrigation in the city of Kaélé
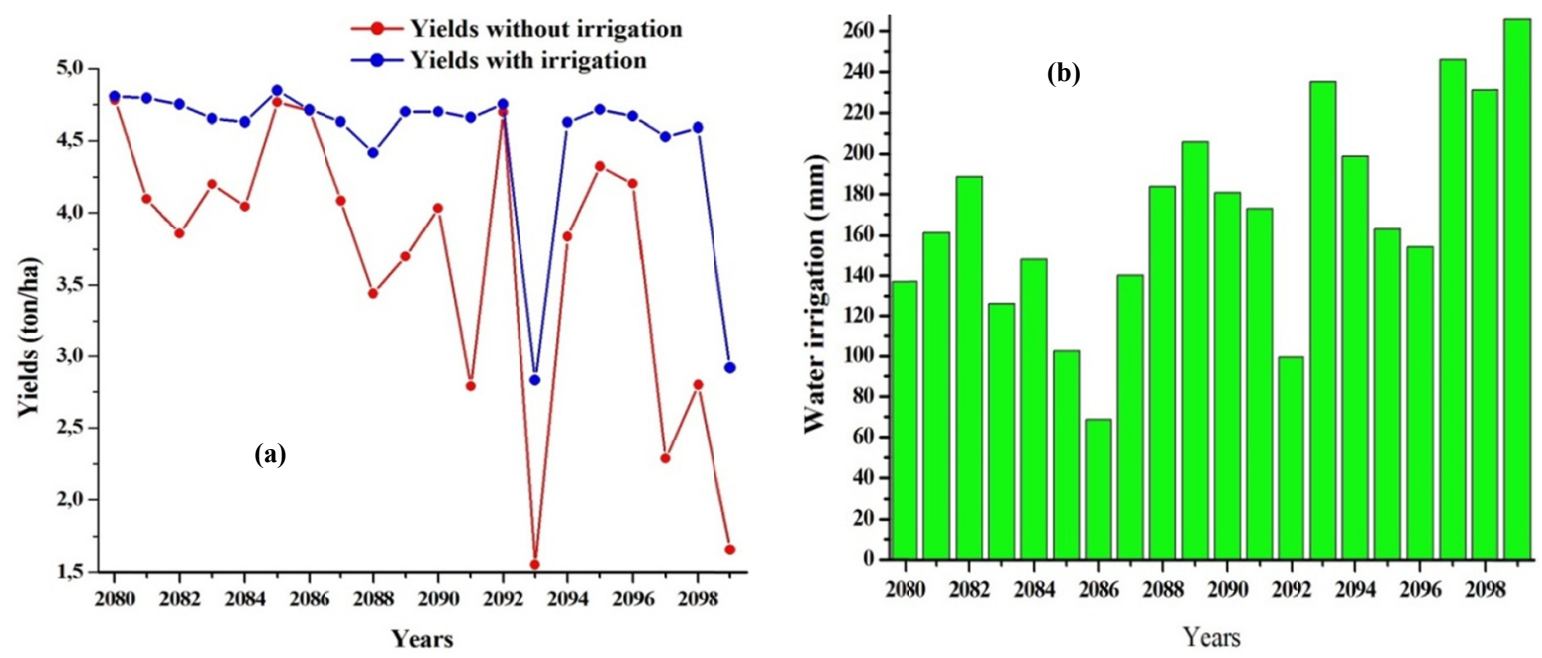

Figure 14. Diagrams showing between 2080 and 2099 in (a) changes in yields of maize with and without irrigation and (b) amounts of water to be supplied for irrigation in the city of Kaélé

These figures show that from 2020 to 2050 except the years 2021, 2024, 2033 and 2042, yields vary very little after irrigation and the irrigation rate is also less than $100 \mathrm{~mm}$. In 2036, this rate of irrigation is zero and indicates that for this year, the amount of water brought by the rains is already sufficient for the normal development of the plants. But for the years 2021, 2024, 2033 and 2042 the rates of irrigation water are respectively 125, 101; 162 and $124 \mathrm{~mm}$. From 2051 to 2099, there are important differences between the yields with irrigation and without irrigation. The quantities of water to be supplied during irrigation are between 10 and $266 \mathrm{~mm}$. Thus, the impacts of climate change in the city of Kaélé on corn will become significant in 2050, earlier than in Garoua.

Figures 15, 16, 17 and 18 show the same for the city of Maroua. These figures show similarities with those corresponding to the city of Maroua. 

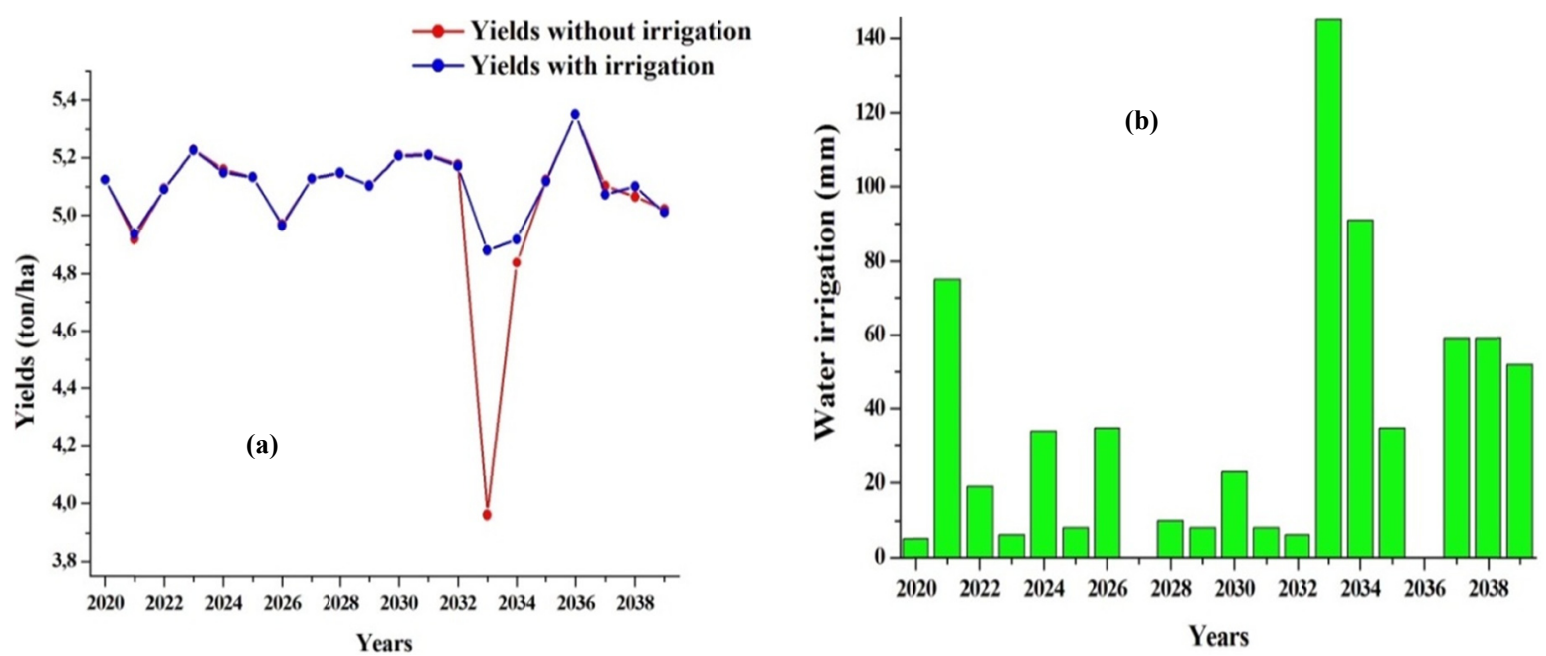

Figure 15. Diagrams showing between 2020 and 2039 in (a) variations in yields of maize with and without irrigation and (b) amounts of water to bring for irrigation in the city of Maroua
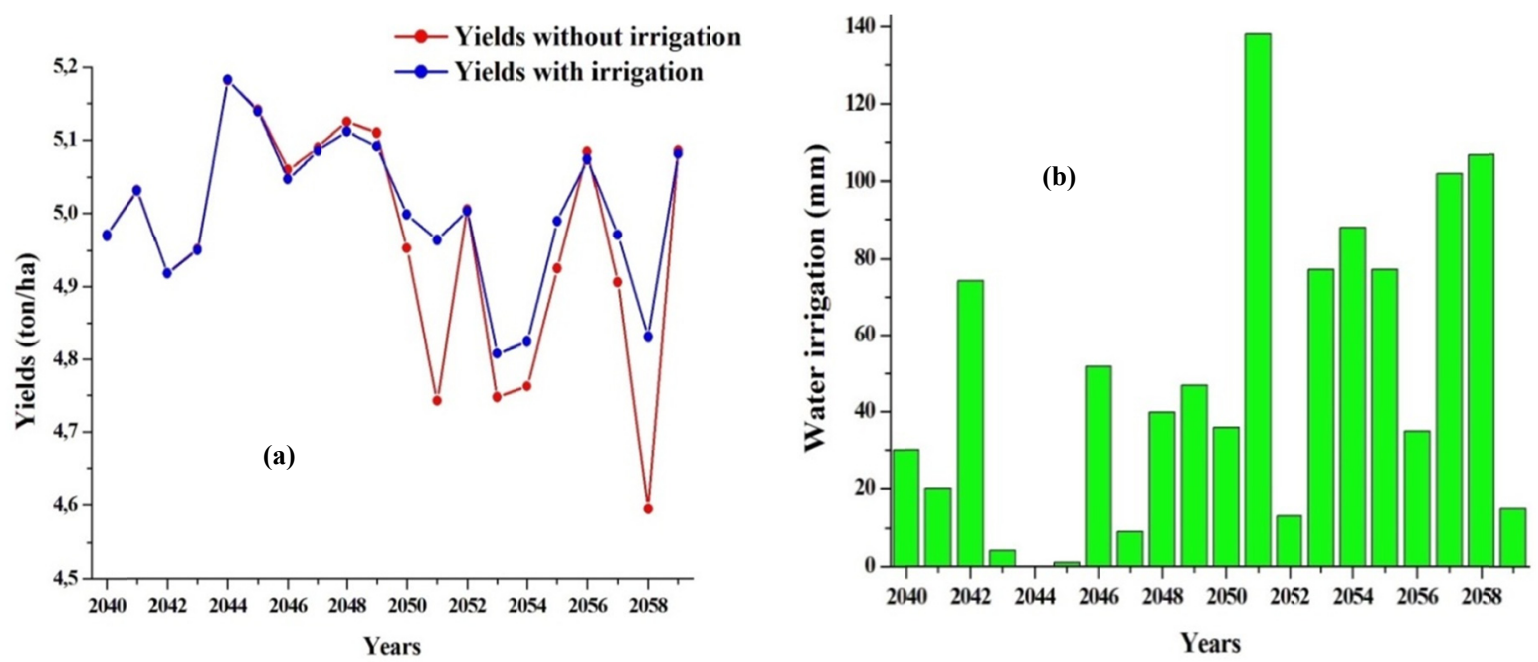

Figure 16. Diagrams showing between 2040 and 2059 in (a) the variations of maize yields with and without irrigation and (b) the quantities of water to bring for irrigation in the city of Maroua
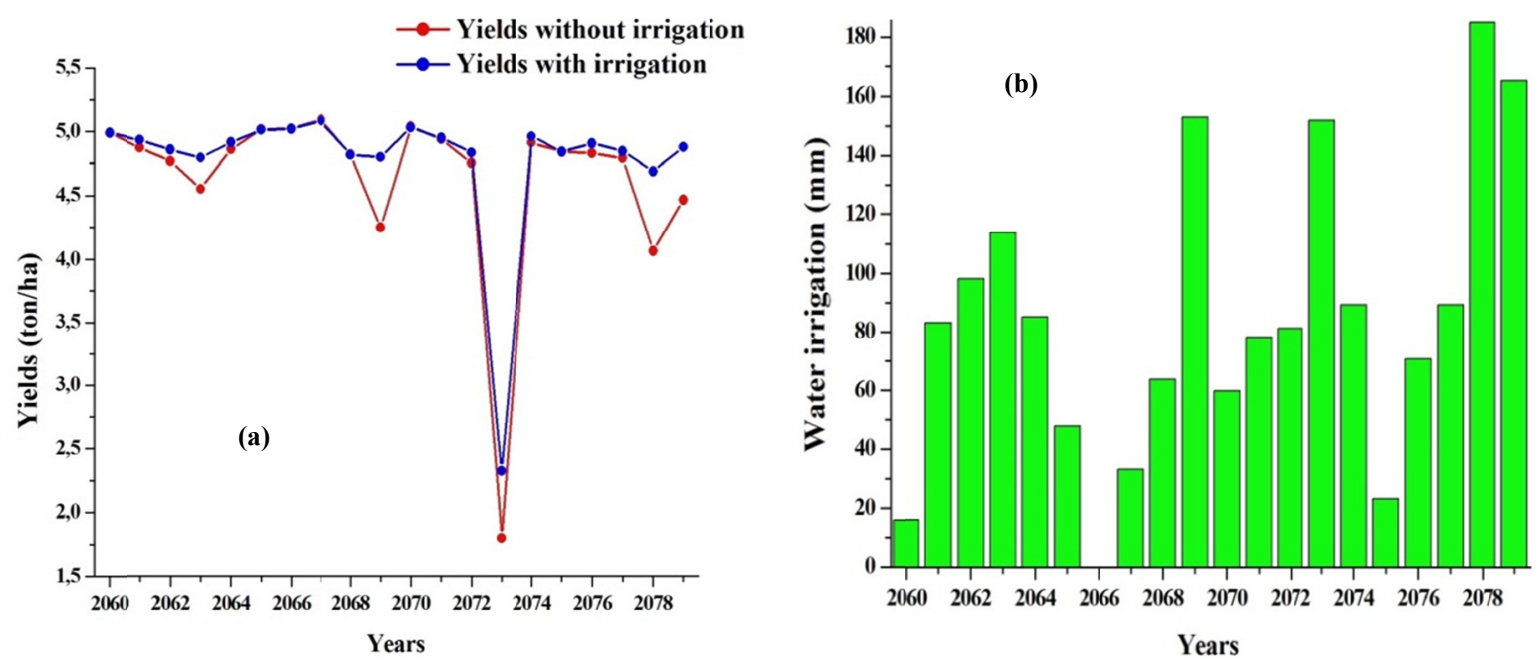

Figure 17. Diagrams showing between 2060 and 2079 in (a) the variations of maize yields with and without irrigation and (b) the quantities of water to bring for irrigation in the city of Maroua 

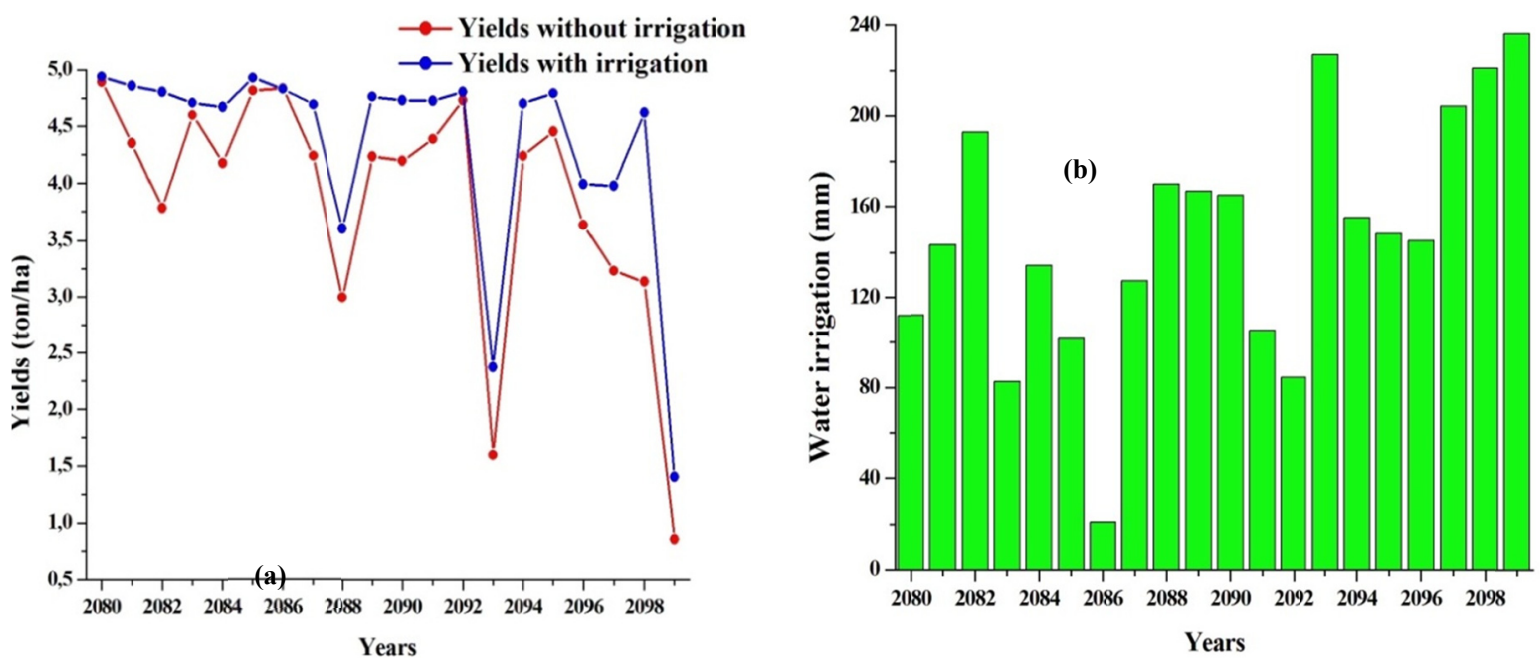

Figure 18. Diagrams showing between 2080 and 2099 in (a) the variations of maize yields with and without irrigation and (b) the quantities of water to bring for irrigation in the city of Maroua

From 2020 to 2079 simulated yields with irrigation vary very little compared to those without irrigation and the quantities of water required for this process also remain less than $100 \mathrm{~mm}$ like in Garoua and Kaélé. Between 2080 and 2099, irrigation rates vary greatly, the minimum rate needed is $21 \mathrm{~mm}$ (2086) and the maximum in 2099 is $236 \mathrm{~mm}$. These rates are slightly different from those observed in the city of Garoua.

In order to better appreciate the contribution of these irrigations in each city during the four periods studied (2020 to 2039, 2040 to 2059,2060 to 2079 and 2080 to 2099), the yields obtained with irrigation are compared with those obtained without irrigation.

Table 8 shows simulated average yields of maize with and without irrigation, the rate of change in these yields, and the average amount of water required for these different study periods.

Table 8. Mean simulated maize yields with and without irrigation and the rate of change of these yields and the average amount of water required for irrigation from 2020 to 2099

\begin{tabular}{|c|c|c|c|c|c|}
\hline Periods studied & Study City & $\begin{array}{l}\text { Average yields without } \\
\text { irrigation in (ton/ha ) }\end{array}$ & $\begin{array}{l}\text { Average yields with } \\
\text { irrigation in (ton/ha ) }\end{array}$ & Rate of change in $(\%)$ & $\begin{array}{l}\text { Average amount of } \\
\text { irrigation water }(\mathbf{m m})\end{array}$ \\
\hline \multirow{3}{*}{ 2020-2039 } & Garoua & 5.21 & 5.20 & -0.20 & 13 \\
\hline & Kaélé & 4.91 & 4.99 & 1.63 & 57 \\
\hline & Maroua & 5.05 & 5.10 & 0.99 & 34 \\
\hline \multirow{3}{*}{ 2040-2059 } & Garoua & 5.11 & 5.10 & -0.20 & 19 \\
\hline & Kaélé & 4.82 & 4.91 & +1.87 & 68 \\
\hline & Maroua & 4.97 & 5.00 & 0.60 & 48 \\
\hline \multirow{3}{*}{ 2060-2079 } & Garoua & 4.97 & 4.99 & 0.40 & 46 \\
\hline & Kaélé & 4.51 & 4.75 & 5.32 & 111 \\
\hline & Maroua & 4.64 & 4.78 & 3.01 & 84 \\
\hline \multirow{3}{*}{ 2080-2099 } & Garoua & 4.73 & 4.82 & 1.90 & 78 \\
\hline & Kaélé & 3.69 & 4.50 & 22.00 & 171 \\
\hline & Maroua & 3.87 & 4.35 & 12.40 & 147 \\
\hline
\end{tabular}

The values of the rate of change in Table 8 confirm the observations done in paragraph 3.2. Indeed, in Garoua, these values are around 0 from 2020 to 2079 showing that the climate will not impact the yields maize cultivations as indicated earlier. After 2079 for this city and for all the study period in Maroua and Kaélé, the rate of change values are significant and indicate that irrigation will improve maize yields. Similarly to the average water amounts, these coefficients increase gradually as we move from one period to another, changing from 2020 to 2099. This indicates that the impacts of climate change in these cities will become more important over 
time as indicated above. Whatever the period studied; it is found that the values of the rate of change and the average quantities of irrigation water increase when one passes from the city of Garoua to that of Maroua and that of Kaélé. As indicated above the city of Kaélé and Maroua are more affected by these climatic changes and the effect is less significant for the city of Maroua.

\section{Conclusions}

The main objective of this work was on the one hand to study the impact of the future climate on maize yields in the cities of Garoua $\left(9^{\circ} 18^{\prime} \mathrm{N}\right.$ and $\left.13^{\circ} 24^{\prime} \mathrm{E}\right)$, Kaélé $\left(10^{\circ} 05^{\prime} 44^{\prime \prime} \mathrm{N}\right.$ and $\left.14^{\circ} 26^{\prime} 37^{\prime \prime} \mathrm{E}\right)$ and Maroua $\left(10^{\circ} 35^{\prime} \mathrm{N}\right.$ and $14^{\circ} 19^{\prime} \mathrm{E}$ ) from Northern Cameroon and on the other hand, to estimate using AquaCrop model the quantities of water needed to improve these yields. The model was first calibrated with the data on the field from 1999 to 2004 and, by using the meteorological data of 2020 to 2099 obtained from the Regional Model (REMO) associated with the MPI-ESM global model of the RCP 8.5 scenario, the future yields were simulated. These yields were compared with those of the reference periods: 1979-2004 for Garoua and Maroua and 1970-1985 for Kaélé.

The results show that the yields obtained with the calibrated parameters are almost nil for the three cities. In the hypothesis of no soil moisture stress to determine the minimum quantity of water needed to remedy to the situation, we noticed that in general yields in the three cities decrease gradually from 2020 to 2099 and are higher in Maroua than in Garoua and Kaélé. These rates vary in general with rainfall, but some exceptions are observed owing the thermal increase. A comparison of simulated average yields over periods of 20 consecutive years with those of the reference periods shows that they decrease from 3 to $12 \%$ for Garoua, from 11 to $33 \%$ for Kaélé and from 8 to $30 \%$ for Maroua. The simulations with irrigation show that these yields are slightly improved in all three cities and the quantities of water needed for irrigation are less than $100 \mathrm{~mm}$ from 2020 to 2078 in the city of Garoua then become more important until 2099. In Maroua, the observation is similar but the quantities of water required for irrigation are greater than $100 \mathrm{~mm}$ from 2080 and yield remain low compared to those of Garoua. In the city of Kaélé, the simulated yields with irrigation are still lower than those of the previous cities and the quantities of water needed for irrigation are less than $100 \mathrm{~mm}$ until 2050 then, increase and the maximum is $266 \mathrm{~mm}$. Irrigation could thus be done to improve maize yields in the three cities and combat their vulnerabilities to climate change.

\section{Acknowledgements}

The authors thank Dr Fotso-Nguemo who has allowed the extraction the future climate data from his work. The authors also thank IRAD for the phonological data of cultivated maize varieties in studied cities. The anonymous reviewers who contributed to a significant update of the manuscript are also thanked.

\section{References}

Abedinpour, M., Sarangi, A., Rajput, T. B. S., \& Singh, M. (2014). Prediction of maize yield under future water availability scenarios using the AquaCrop model. Journal of Agricultural Science, 152(04), 558-574. https://doi.org/10.1017/S0021859614000094

Agritrade. (2011). SADC: Agricultural trade policy debates and developments. Technical Center for Agricultural Trade and Rural Cooperation (ACP-EU). Retrieved from https://agritrade.cta.int/Agriculture/Regions/ ACP/Central-Africa/Executive-Brief-Update-2013Central-Africa-Agricultural-trade-policy-debates-and-de velopments.html

Bigot, S. (1997). Les précipitations et la convection profonde en Afrique centrale: Cycle saisonnier, variabilité interannuelle et impact sur la végétation (Thèse de Doctorat, Université de Bourgogne, Centre de Recherches de Climatologie).

Brisson, N., Mary, B., Ripoche, D., Jeuffroy, M. H., Ruget, F., Nicoullaud, B., ... Delécolle, R. (1998). STICS: A generic model forthe simulation of crops and their water and nitrogen balances. I. Theory and parametrization applied to wheat and corn. Agronomie, 18(5-6), 311-346. https://doi.org/10.1051/agro: 19980501

Chabejong, N. E. (2016). A review on the impact of climate change on food security and malnutrition in the Sahel region of Cameroon. In W. Leal Filho, U. Azeiteiro, \& F. Alves (Eds.), Climate Change and Health (pp. 133-148). Springer International Publishing, Cham, Switzerland. https://doi.org/10.1007/978-3-31924660-4_9 
Chebil, A., Mtimet, N., \& Tizaoui, N. (2011). Impact du changement climatique sur la productivité des cultures céréalières dans la région de Béja (Tunisie). African Journal of Agricultural and Resource Economics, 6(2), 144-154.

Chuku, C. A., \& Okoye, C. (2009). Increasing resilience and reducing vulnerability in subSaharan African agriculture: Strategies for risk coping and management. African Journal of Agricultural Research, 4, 1524-1535.

Davies, H. C. (1976). A lateral boundary formulation for multilevel prediction models. Quarterly Journal of the Royal Meteorological Society, 102, 405-418. https://doi.org/10.1002/qj.49710243210

De Wit, C. T. (1958). Transpiration and crop yields. Verslagen van Landbouwkundige Onderzoekingen, Agricultural Research Report, 64(6), 1-88.

Donfack, F. C., Lenouo, A., \& Tchawoua, C. (2018). Water Requirements for Corn Yields in the Northern Regions of Cameroon Using AquaCrop Model. Journal of Agriculture and Ecology Research International, 16(3), 1-11. https://doi.org/10.9734/JAERI/2018/44993

Doorenbos, J., \& Kassam, A. H. (1979). Yield Response to Water. Irrigation and Drainage Paper No. 33. FAO, United Nations Rome, Italy.

Doukpolo, B., Ogouwalé, E., Ndjendolé, S., \& Boko, M. (2012). Impacts potentiels des changements climatiques sur les cultures du maïs et du coton et stratégies d'adaptation dans l'Ouham en Centrafrique (pp. 243-248). Publication de l'Association Internationale de Climatologie, XXVe Colloque.

Epule, T. E., \& Bryant, C. R. (2015). Maize production responsiveness to land use change and climate trends in Cameroon. Sustainability, 7(1), 384-397. https://doi.org/10.3390/su7010384

FAO. (2020). Information resources for SCPI. Food Agriculture Organization of the United Nations. Retrieved from http://www.fao.org/agriculture/crops/thematic-sitemap/theme/spi/scpi-home/framework2/en

Ferris, G. R., Arthur, M. M., Berkson, H. M., Kaplan, D. M., Harrell-Cook, G., \& Frink, D. D. (1998). Toward a social context theory of the human resource management organization effectiveness relationship. Human Re source Management Review, 8(3), 235-264. https://doi.org/10.1016/S1053-4822(98)90004-3

Forum pour le Partenariat avec l'Afrique. (2007). Les changements climatiques et l'Afrique. 8ème Réunion du Forum pour le Partenariat avec l'Afrique Berlin, Allemagne.

Fotso-Nguemo, T. C., Vondou, D. A., Tchawoua, C., \& Haensler, A. (2016). Assessment of simulated rainfall and temperature from the regional climate model REMO and future changes over Central Africa. Climate Dynamics, 48(11-12), 3685-3705. https://doi.org/10.1007/s00382-016-3294-1

Giorgetta, M., \& Wild, M. (1995). The water vapour continuum and its representation in ECHAM4. MPI Report No. 162. Max Planck Institut für Meteorologie, Hamburg, Germany. Retrieved from http://hdl.handle.net/ 11858/00-001M-0000-0019-B569-F

Hagemann, S. (2002). An improved land surface parameter dataset for global and regional climate models. MPI Report No. 336. Max Planck Institute for Meteorology, Hamburg, Germany. https://doi.org/10.17617/ 2.2344576

Hanks, R. J. (1983). Yield and water-use relationships. In H. M. Taylor, W. R. Jordan, \& R. Sinclair (Eds.), Limitations to efficient water use in crop production (pp. 393-411). American Society of Agronomy, Crop Science Society of America, Soil Science Society of America Journal.

Hsiao, T. C., Heng, L., Steduto, P., Rojas-Lara, B., Raes, D., \& Fereres, E. (2009). AquaCrop: The FAO crop model to simulate yield response to water: III. Parameterization and testing for maize. Agronomy Journal, 101(3), 448-459. https://doi.org/10.2134/agronj2008.0218s

Inoussa, B. (2010). The Effects of Drought on Crop Yields and Yield Variability in Sahel. International Journal of Economics and Finance, 4(12). https://doi.org/10.5539/ijef.v4n12p51

IPCC. (2007). Summary for Policy makers. In M. L. Parry, O. F. Canziani, J. P. Palutikof, P. J. Vander Linden, \& C. E. Hanson (Eds.), Climate Change Impacts, Adaptation and Vulnerability. Contribution of Working Group II to the 4AR of the IPCC (pp. 7-22). Cambridge University Press, Cambridge, UK.

Issa, M. S. (2012). Changements climatiques et agrosystèmes au Bénin central: Impacts et stratégies d'adaptation (Thèse de doctorat unique de Géographie, université d'Abomey-Calavi, Laboratoire Pierre PAGNEY Climat, Eau, Ecosystèmes et Développement). 
Jamieson, P. D., Porter, J. R., \& Wilson, D. R. (1991). A test of computer simulation model ARC-WHEAT1 on wheat crops grown in New Zealand. Field Crops Research, 27, 337-350. https://doi.org/10.1016/0378-4290 (91)90040-3

Jones, J. W., Hoogenboom, G., Porter, C. H., Boote, K. J, Batchelor, W. D., Hunt, L. A., ... Ritchie, J. T. (2003). DSSAT Cropping System Model. European Journal of Agronomy, 18(3-4), 235-265. https://doi.org/ 10.1016/S1161-0301(02)00107-7

Kate, S., Teka, O., Chabi, R. B., Djikpo, R., Ogouwalé, E., Tenté, B. A. H., \& Sinsin, B. (2017). Simulation du climat futur et des rendements agricoles en région soudano-sahélienne en république du bénin. African Crop Science Journal, 25(4), 405-417. https://doi.org/ 10.4314/acsj.v25i4.2

Lohmann, U., \& Roeckner, E. (1996). Design and performance of a new cloud microphysics scheme developed for the ECHAM4 general circulation model. Climate Dynamics, 12, 557-572. https://oi.org/10.1007/ BF00207939

Louis, J. F. (1979). A parametric model of vertical eddy fluxes in the atmosphere. Boundary-Layer Meteorology, 17, 187-202. https://doi.org/10.1007/BF00117978

McCown, R. L., Hammer, G. L., Hargreaves, J. N. G., Holzworth, D. P., \& Freebairn, D. M. (1996). APSIM: A novel software system for model development, model testing and simulation in agricultural systems research. Agricultural Systems, 50, 255-71. https://doi.org/10.1016/0308-521X (94)00055-V

Melki, M., Dahmane, K., \& Garoui, A. (1995). Effet de la variation saisonnière des facteurs climatiques sur les composantes du rendement des céréales (blé dur et orge). Revue de l'INAT, 10(1), 105-14

Molua, E., \& Lambi, C. (2006). The economic impact of climate change on agriculture in Cameroon. CEEPA Discussion Paper No. 17. Centre for Environmental Economics and Policy in Africa, University of Pretoria. https://doi.org/10.1596/1813-9450-4364

Morcrette, J., Smith, L., \& Fourquart, Y. (1986). Pressure and temperature dependance of the absorption in longwave radiation parameterizations. Contributions to Atmospheric Physics, 59, 455-469.

Mwangi, P., Karanja, F., Mwende, J., \& Ogara, W. (2019). Application of AquaCrop Model for Sorghum Yield Projections and Scenarios Development under Rainfed Farming at Wiyumiririe Laikipia County Kenya. East African Scholars Journal of Agriculture and Life Sciences, 2(8), 420-432.

Nordeng, T. E. (1994). Extended versions of the convective parametrization scheme at ECMWF and their impact on the mean and transient activity of the model in the tropics (No. 206, p. 41). ECMWF Research Department, Technical Momorandum, European Centre for Medium Range Weather Forecasts.

Olivier, D., Bernoux, M., Chauveau, M., Lucas, C., \& Chazot, S. (2016). Étude de l'effet du changement climatique sur le potentiel de développement des productions végétales en Russie, Ukraine, Kazakhstan à Moyen Terme.

Oyekunle, M., \& Badu-Apraku, B. (2014). Genetic Analysis of Grain Yield and Other Traits of Early-Maturing Maize Inbreds under Drought and Well-Watered Conditions. Journal of Agronomy and Crop Science, 200, 92-107. https://doi.org/10.1111/jac.12049

Pfeifer, S. (2006). Modeling cold cloud processes with the regional climate model REMO (PhD Thesis, University of Hamburg, Hamburg). https://doi.org/10.17617/2.994658

Raes, D., Steduto, P., Hsiao, T. C., \& Fereres, E. (2009). AquaCrop: The FAO crop model to simulate yield response to water: II. Main algorithms and software description. Agronomy Journal, 101(3), 438-447. https://doi.org/10.2134/agronj2008.0140s

Salack, S., Traoré, B. S., \& Sarr, B. (2006). Synthèse sur la collecte, la mise en forme et le stockage des données climatologiques des pays du CILSS, et Etude d'impacts des changements climatiques sur la production agricole au Sahel. Rapport de stage, Centre Régional AGRHYMET.

Seck, M., \& Moussa, N. A. (2005). Adaptation aux Changements Climatiques: L'étude de cas des systèmes de production agricoles de Sébikotane (Sénégal). Linking Climate Adaptation Project, ENDA Tiers-Monde.

Steduto, P., Hsiao, T. C., \& Fereres, E. (2007). On the conservative behavior of biomass water productivity. Irrigation Science, 25, 189-207. https://doi.org/10.1007/s00271-007-0064-1 
Steduto, P., Hsiao, T. C., Raes, D., \& Fereres, E. (2009). AquaCrop-The FAO crop model to simulate yield response to Water, I. Concepts and underlying principles. Agronomy Journal, 101(3), 426-437. https://doi.org/10.2134/agronj2008.0139s

Stöckle, C. D., Donatelli, M., \& Nelson, R. (2003). Cropsyst, a cropping systems simulation model European. Journal of Agronomy, 18(3-4), 289-307. https://doi.org/10.1016/S1161-0301 (02)00109-0

Supit, I., Hooyer, A. A., \& Van Diepen, C. A. (1994). System description of the WOFOST 6.0 crop simulation model implemented in the CGMS Vol 1: Theory and alogorithms. Office for the Official Publications of the European Communities, Luxembourg.

Tanner, C. B., \& Sinclair, T. R. (1983). Efficient water use in crop production: Research or re-search? In H. M. Taylor, W. R. Jordan, \& T. R. Sinclair (Eds.), Limitations to efficient water use in crop production (pp. 1-27). ASA, CSSA, and SSSA, Madison, WI. https://doi.org/10.2134/1983.limitationstoefficientwateruse.c1

Tiedtke, M. (1989). A Comprehensive Mass Flux Scheme for Cumulus Parameterization in Large Scale Models. Monthly Weather Review, 117(8), 1779-1800. https://doi.org/10.1175/1520-0493(1989)117<1779:ACMFSF> 2.0.CO;2

Williams, J. R., Jones, C. A., Kiniry, J. R., \& Spanel, D. A. (1989). The EPIC crop growth model. Transactions of the American Society of Agricultural Engineers, 32(2), 479-511. https://doi.org/10.13031/2013.31032

\section{Copyrights}

Copyright for this article is retained by the author(s), with first publication rights granted to the journal.

This is an open-access article distributed under the terms and conditions of the Creative Commons Attribution license (http://creativecommons.org/licenses/by/4.0/). 